\title{
URBAN AND RURAL MARRIAGE PATTERNS IN IMPERIAL GERMANY
}

\author{
John Knodel and Mary Jo Maynes*
}

Much of the historical research on marriage has centered on the relationship between proto-industrialization or industrialization and changes in opportunities for marriage. The standard historical argument was summarized a decade ago by D. E. C. Eversley (1965:45): the ability to marry was contingent, in pre-industrial societies, upon access to land in the peasant economy; in the cities guilds "were supposed to be powerful bars to marriage." When the system broke down, so the argument goes, "an urban proletariat was created, at least in some cases, and this may have led to a lowering of the age at marriage, and the shedding of all prudential restraint." Eversley himself disagreed with this interpretation but nonetheless expected a possible lowering of marriage age in the industrial sector "as the response ... to increased employment opportunity." But he also pointed out that both age at marriage and proportions remaining single for life remained fairly constant over the period of European industrialization.

Demographic and social historians have

*John Knodel is Associate Professor of Sociology and Research Associate, Population Studies Center, University of Michigan. Mary Jo Maynes is a graduate student in the Department of History, University of Michigan.

We wish to thank Etienne and Francine van de Walle, Barbara Anderson, Allan Sharlin, and Massimo Livi Bacci for providing some of the data; Steven Hochstadt, Karen Mason, Louise Tilly, Mirmiam Cohen, Michael Haines, and Ron Lee offered useful comments on an earlier draft. frequently concentrated on the specific relationship between proletarianization and nuptiality; much of the literature on this question has resulted from the attempt to explain the population growth which accompanied European industrialization. For example, W. Petersen (1960), in analysing the demographic transition in the Netherlands, emphasized the traditional importance of marriage-regulating devices. The pervasive principle "that a man might not marry until his living was assured" constrained population growth in pre-industrial Netherlands. But the early modern creation of a landless proletariat and increased migration to the cities where "livings" were more easily established allowed increases in nuptiality (that is, the proportion of the population which would eventually marry) and, Petersen speculates, may also have lowered the age at which people married. Both of these changes would contribute to a rise in general fertility, causing population growth.

H. J. Habakkuk, in his analysis of the relationship between economic and demographic change in England maintains that there "seems nothing improbable in supposing that, on balance, the group which as a result of economic changes were becoming larger had also a relative lower age at marriage, and that the shifts were great enough to produce changes in the average marriage age of real significance for population growth" (1965:154).

L. Tilly, J. Scott, and M. Cohen (1976) in their recent article on women's work 
and fertility suggest a possible relationship between new conditions of work and changing opportunities for marriage as they affected the female labor force. Industrialization and urbanization both play a role in their model. Beginning at the end of the eighteenth century more and more women were being forced to find work outside the home and in the city than ever before. And the character of urban life may have encouraged working women to marry; as they put it:

A number of pressures impelled young working girls to find mates. One was the loneliness and isolation of work in the city. Another was economic need: Wages were low and employment for women, unstable. The logical move for a single girl far from her family would be to find a husband with whom she might re-establish a family economy. Yet another pressure was the desire to escape the confines of domestic service. . . (1976:464).

While everyone agrees that the historical relationship between socio-economic change and nuptiality is a complex one, there is nonetheless a sense that population increase in Europe was made possible through a decreasing age at marriage; changes in nuptiality patterns were, in turn, connected with the broad structural changes that produced huge cities with large proletarian populations and rural economies with increasing propertyless sectors. Presumably, such demographic impact would be most noticeable where proletarian populations were most concentrated. Accordingly, one would expect to find earlier and more universal marriage in urban, industrialized areas.

While this historical interpretation is relatively new, as is the sympathy with the difficulties and aspirations of the propertyless, concern with the issue itself is not new; contemporary commentators from the time of Malthus viewed with alarm the tendency of the poor to be nonchalant about marriage and reproduction. The statistician J. E. Wappäus, writing in the 1860 s, saw the growing cities as the seedbeds of moral irresponsibility. In a book on population statistics he wrote:

In general, the number of marriages adjusts itself to the greater or lesser ease with which the means of subsistence necessary for the support of a family can be acquired ... it is only in certain instances that one can observe an increase in the number of marriages to be the result of improvidence, with new families being formed without assured and sufficient income. And this is, in fact, very often the case in large cities and factory regions, wherever the laws do not prevent it (1861:237).

In the city, it was assumed, people married irresponsibly, and young. Wappäus made his assertions based on nuptiality rates (marriages/population) and failed to realize that his facts were distorted by the tendency for young adults, that is, the people most likely to be getting married, to be more preponderant in urban than in rural populations. But while his use of statistics was faulty, the concern of Wappäus and many others like him about perceived problems of urban immorality and industrial overpopulation led to the collection of census data useful for the historical analysis of nuptiality. In particular, this data allows the study of urban-rural and regional differences in marriage patterns.

Given the extensive data on age and marital status provided separately for rural and urban sectors of the populations in many nineteenth-century censuses, the question of whether or not the institution of marriage was altered by the urban setting can be more fully explored. In particular, the hypothesis that marriage was earlier and more universal in urban than in rural areas can be carefully examined.

The present study focuses on one European nation, Germany, reviewing in detail the empirical evidence on rural-urban differences in marriage patterns around 1880 , a period when Germany was emerging as a modern, industrial nation. German regions and communities were 
characterized by a diversity of socio-economic and demographic conditions at this time, including rapid industrialization and urbanization in the Ruhr Valley, manorial agriculture in East Prussia, and peasant farming in Bavaria. In various border areas, the considerable ethnic diversity meant a mixing of cultural patterns of Danes, Czechs, and Poles with those of the ethnic Germans. For these reasons, we believe Germany makes a useful case study.

In Table 1, the rural-urban marriage patterns in the three largest German states are compared with those of several European countries around 1880 . The measures themselves are discussed in detail below. The pattern for the German

TABLE 1. MEASURES OF NUPTIALITY FOR SELECTED COUNTRIES AND LARGER GERMAN STATES CA. 1880 BY RURAL AND URBAN RESIDENCE

\begin{tabular}{|c|c|c|c|c|c|c|}
\hline \multirow{3}{*}{$\begin{array}{l}\text { Country or state and } \\
\text { type of residence }\end{array}$} & \multicolumn{3}{|c|}{ Men } & \multicolumn{3}{|c|}{ Women } \\
\hline & \multicolumn{2}{|c|}{$\%$ Single } & \multirow[b]{2}{*}{ SMAM } & \multicolumn{2}{|c|}{$\%$ Single } & \multirow[b]{2}{*}{ SMAM } \\
\hline & $25-29$ & $45-49$ & & $20-24$ & $45-49$ & \\
\hline \multicolumn{7}{|l|}{ Prussia, 1880} \\
\hline $\begin{array}{l}\text { rural } \\
\text { urban under } 20,000 \\
\text { urban } 20,000+\end{array}$ & $\begin{array}{l}49.7 \\
52.5 \\
55.2\end{array}$ & $\begin{array}{l}7.6 \\
8.4 \\
9.3\end{array}$ & $\begin{array}{l}27.91 \\
28.29 \\
28.47\end{array}$ & $\begin{array}{l}72.3 \\
74.8 \\
77.1\end{array}$ & $\begin{array}{r}8.0 \\
11.3 \\
132\end{array}$ & $\begin{array}{l}25.42 \\
25.67 \\
26.07\end{array}$ \\
\hline \multicolumn{7}{|l|}{ Sachsen, 1880} \\
\hline $\begin{array}{l}\text { rural } \\
\text { towns } \\
\text { large cities }\end{array}$ & $\begin{array}{l}35.0 \\
37.5 \\
53.4\end{array}$ & $\begin{array}{l}4.9 \\
5.6 \\
8.9\end{array}$ & $\begin{array}{l}26.46 \\
26.91 \\
28.43\end{array}$ & $\begin{array}{l}67.9 \\
67.5 \\
77.4\end{array}$ & $\begin{array}{r}6.7 \\
6.9 \\
14.0\end{array}$ & $\begin{array}{l}24.72 \\
24.75 \\
26.07\end{array}$ \\
\hline \multicolumn{7}{|l|}{ Bavaria, 1880} \\
\hline $\begin{array}{l}\text { rural } \\
\text { urban under } 20,000 \\
\text { urban } 20,000+\end{array}$ & $\begin{array}{l}60.7 \\
60.2 \\
63.3\end{array}$ & $\begin{array}{l}12.6 \\
11.6 \\
12.2\end{array}$ & $\begin{array}{l}28.80 \\
29.12 \\
29.45\end{array}$ & $\begin{array}{l}78.7 \\
77.2 \\
80.1\end{array}$ & $\begin{array}{l}15.8 \\
19.5 \\
19.8\end{array}$ & $\begin{array}{l}25.46 \\
25.10 \\
26.21\end{array}$ \\
\hline \multicolumn{7}{|l|}{ Belgium, 1880} \\
\hline $\begin{array}{l}\text { rural } \\
\text { urban }\end{array}$ & $\begin{array}{l}64.1 \\
49.6\end{array}$ & $\begin{array}{l}20.1 \\
16.3\end{array}$ & $\begin{array}{l}29.50 \\
27.70\end{array}$ & $\begin{array}{l}77.1 \\
75.3\end{array}$ & $\begin{array}{l}17.6 \\
20.8\end{array}$ & $\begin{array}{l}26.90 \\
25.68\end{array}$ \\
\hline \multicolumn{7}{|l|}{ Denmark, 1880} \\
\hline $\begin{array}{l}\text { rural } \\
\text { urban }\end{array}$ & $\begin{array}{l}57.3 \\
56.4\end{array}$ & $\begin{array}{r}7.9 \\
12.1\end{array}$ & $\begin{array}{l}29.01 \\
28.79\end{array}$ & $\begin{array}{l}79.7 \\
80.2\end{array}$ & $\begin{array}{r}8.4 \\
17.9\end{array}$ & $\begin{array}{l}27.14 \\
27.09\end{array}$ \\
\hline \multicolumn{7}{|l|}{ England and Wales, 1881} \\
\hline $\begin{array}{l}\text { London } \\
\text { Lon Lonaon }\end{array}$ & $33.2^{\mathrm{c}}$ & $9.6^{\mathrm{d}}$ & 27.34 & $\begin{array}{l}65.8^{c} \\
67.9^{c}\end{array}$ & $14.6^{\mathrm{d}}$ & $\begin{array}{l}25.76 \\
26.32\end{array}$ \\
\hline \multicolumn{7}{|l|}{ Norway, 1875} \\
\hline $\begin{array}{l}\text { rural } \\
\text { urban }\end{array}$ & $\begin{array}{l}58.8 \\
54.0\end{array}$ & $\begin{array}{l}10.4 \\
11.5\end{array}$ & $\begin{array}{l}29.23 \\
28.37\end{array}$ & $\begin{array}{l}80.3 \\
80.0\end{array}$ & $\begin{array}{l}14.2 \\
17.8\end{array}$ & $\begin{array}{l}27.60 \\
27.29\end{array}$ \\
\hline \multicolumn{7}{|l|}{ Switzerland, 1880} \\
\hline $\begin{array}{l}\text { rural } \\
\text { urban }\end{array}$ & $\begin{array}{l}59.3 \\
56.2\end{array}$ & $\begin{array}{l}18.7 \\
14.1\end{array}$ & $\begin{array}{l}28.80 \\
28.62\end{array}$ & $\begin{array}{l}75.9 \\
79.1\end{array}$ & $\begin{array}{l}18.7 \\
21.4\end{array}$ & $\begin{array}{l}25.70 \\
26.27\end{array}$ \\
\hline \multicolumn{7}{|l|}{ European Russia, 1897} \\
\hline rural & $35.4^{\mathrm{e}}$ & $2.9^{f}$ & 23.54 & $20.2^{\mathrm{e}}$ & $4.1^{\mathrm{f}}$ & 21.16 \\
\hline urban & $60.0^{\mathrm{e}}$ & $10.5^{f}$ & 26.58 & $37.5^{\mathrm{e}}$ & $11.7^{f}$ & 23.11 \\
\hline \multicolumn{7}{|l|}{ Austria, 1890} \\
\hline $\begin{array}{l}\text { rural (under } 2000 \text { ) } \\
\text { urban } 2000-20,0000\end{array}$ & $63.6^{\mathrm{e}}$ & $12.4^{\mathrm{f}}$ & 26.89 & $46.2^{\mathrm{e}}$ & $13.8^{f}$ & 23.71 \\
\hline $\begin{array}{l}\text { urban } 2000-20,000 \\
\text { urban } 20,000+\end{array}$ & $68.8^{\mathrm{e}}$ & $15.0^{f}$ & 27.53 & $49.2^{\mathrm{e}}$ & $17.1^{f}$ & 24.16 \\
\hline urban $20,000+$ & $79.9^{\mathrm{e}}$ & $17.3^{f}$ & 29.23 & $63.6^{\mathrm{e}}$ & $20.9^{f}$ & 26.41 \\
\hline
\end{tabular}

Notes: The definition of rural and urban varies from country to country.

SMAM $=$ singulate mean age at marriage- - See text for explanation of measure.

all urban places except the cities of Dresden, Leipzig, and Chemnitz.

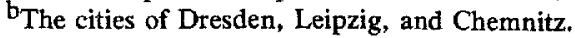

$c_{25-34}$

$\mathrm{d}_{45-54}$

e $20-29$

$\mathrm{f}_{40-49}$ 
states indicates that marriage was later and the proportions remaining single were greater in urban areas. Although there is variation in the extent and direction of rural-urban nuptiality differences at the national level, the German case is not unique. For every country the proportion still single among women at ages $45-49$ is higher in urban than rural areas. The pattern is less consistent for men but in a number of the countries, men are also more likely to be single by ages of $45-49$ in cities than in the countryside. The rural-urban pattern for age of marriage is mixed for both sexes but more often than not the urban population is characterized by later marriage. Additional data from the 1871 Italian census, indicates for that country the proportion of women 15-49 who were married was considerably lower in the cities and that the proportion single among women 50-54 was higher in all the large cities than in the remainder of the provinces in which they were located (Livi Bacci, 1976). Thus in much of Europe, as in Germany, in the latter part of the nineteenth century, it appears that the city was not a place of younger and more universal marriage.

It is also worth pointing out that the rural-urban differences in marriage patterns observed in $\mathbf{1 8 8 0}$ in Germany appear to be typical at least of the entire latter part of the nineteenth century in that country and perhaps for earlier periods as well. For example in Prussia, according to the 1867 census, the earliest census for which the requisite data are available separately for rural and urban areas, as well as in 1900 , the singulate mean age at marriage and the proportion single at ages 40-49 are higher in urban than rural areas for both sexes. Thus although our choice of 1880 was based in part on the fact that the rural-urban census data are available for more German states in that year than any other census year in the last half of the nineteenth century, the period is not unusual with respect to patterning of rural-urban nuptiality differences.

\section{Measures and Data}

In the present study we are concerned primarily with two aspects of nuptiality patterns: the age of marriage and the proportion who never marry. ${ }^{1}$ Although marriage rates and age at marriage are frequently based on marriage registration data, descriptions of marriage patterns can also be derived from age-sex-marital status tabulations typically provided in modern censuses. By assuming that the proportions single at successive ages as reported in a given census year corresponds roughly to the proportions single that would characterize a cohort as it ages, it is possible to estimate not only the proportion that never marry but also the average age at first marriage for those who do marry. ${ }^{2}$ The use of proportions single as a tool for the study of marriage habits, originally spelled out in detail by Hajnal (1953), has come into frequent use in demographic studies (e.g., van de Walle, 1968; Dixon, 1971; Sklar, 1974). This approach to measuring marriage patterns is generally convenient for the study of rural-urban nuptiality in nineteenth-century Europe since contemporary censuses typically provide separate age-sex-marital status tabulations for the rural and urban sectors of the population; this is the approach used in the present study.

The calculation of proportions single and estimates of the mean age at marriage

'Occasionally we will also examine the proportion single among women $20-24$ and among men 25-29. These age groups were selected since they are particularly sensitive to differences in marriage behavior within the range of nuptiality experience found in late nineteenth-century Germany.

${ }^{2}$ The rubric "single" refers literally to those who have never been married and does not include widowed or divorced persons. 
from census data is quite straightforward. ${ }^{3}$ The proportion who never marry, sometimes referred to as the extent of permanent celibacy, is measured by the proportion single among persons at an age past which first marriage rarely occurs (in the present study, the percent single among persons aged $45-49$ is used); the age at marriage (called singulate mean age of marriage-SMAM-when computed in this manner) is derived from the changes in proportions single between succussive ages up to age $50 .{ }^{4}$ It is important to realize, however, that the proportions single are a product of other influences besides nuptiality behavior: differentials in mortality and migration effect the proportion single at each age over and above the effect of each cohort's marriage experience. Both mortality rates and migration rates are typically higher for the single than the married populations and thus deaths or out-migration can reduce the

${ }^{3}$ The measurement of marriage patterns from census data including the extent of possible biases is discussed in detail by Hajnal (1953, especially Appendices I-IV) and Agarwala (1962).

'Since the proportions single for age groups 20-24 and $25-29$ play an important part in the computation of the singulate mean age at marriage, it is not suprising that these measures and the singulate mean age of marriage are highly intercorrelated: for the 71 administrative areas in Germany in 1880 , the singulate mean age at marriage correlates .98 with the proportion single 25-29 for men and .79 with the proportion single $20-24$ for women. On the other hand, the proportion single at the end of the marriageable ages does not automatically influence the calculation of the singulate mean age of marriage. (Strictly speaking this would be true if we took the proportion single at age 50 rather than ages $45-49$ as the measure of permanent celibacy.) Nevertheless, for German administrative areas in 1880 the singulate mean age of marriage correlates .82 with the proportion single 45-49 for men; for women, the correlation is only . 35 and thus much weaker. Since these latter correlations. are not artifacts of our measures they must be considered as part of the empirical pattern of marriage at the time. proportion single at successive ages even in the absence of additional marriages.

The effect of mortality differentials on urban-rural differences in nuptiality is probably minimal. The impact of migration, however, is more serious and tends to lower our measures of proportions single and singulate mean age at marriage for rural populations and raise them for urban populations. Problems associated with using these measures for studying urban and rural nuptiality patterns are discussed in more detail in the appendix. Although it is difficult to state exactly how much effect migration exerts on our measures, it is fair to say that while not insignificant, the effect is not sufficient to account for most of our results.

Data for the present study comes from officially published statistics derived from the 1880 census of the Imperial Statistical Bureau (Statistisches Reichsamt) and the various state statistical bureaus. ${ }^{5}$ For the present study, Germany is divided into a number of administrative areas described elsewhere (See Map 1). ${ }^{6}$ The requisite data for the calculation of separate rural and urban nuptiality indices for an administrative area, however, are not universally available; for 1880 separate rural and urban age-sex-marital status distributions were available for 61 of the total 74 administrative areas and for one larger unit representing four administrative areas. ${ }^{7}$ The loss of coverage is not seri-

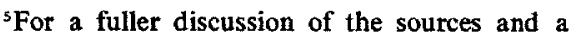
bibliography of the official statistical series used see Knodel (1974), especially pages 19-23 and 292-293.

'An extensive description of the method of defining the administrative areas used as the units of analysis can be found in Knodel (1974:9-14). The method used here was a slight modification which keeps as separate areas the Regierungsberzirke Gumbinnen, Konnigsberg, Stettin, and Stralsund in Prussia and the Kreishauptmannschaften Bautzen and Dresden in Saxony.

'In addition, data is available for Berlin for 


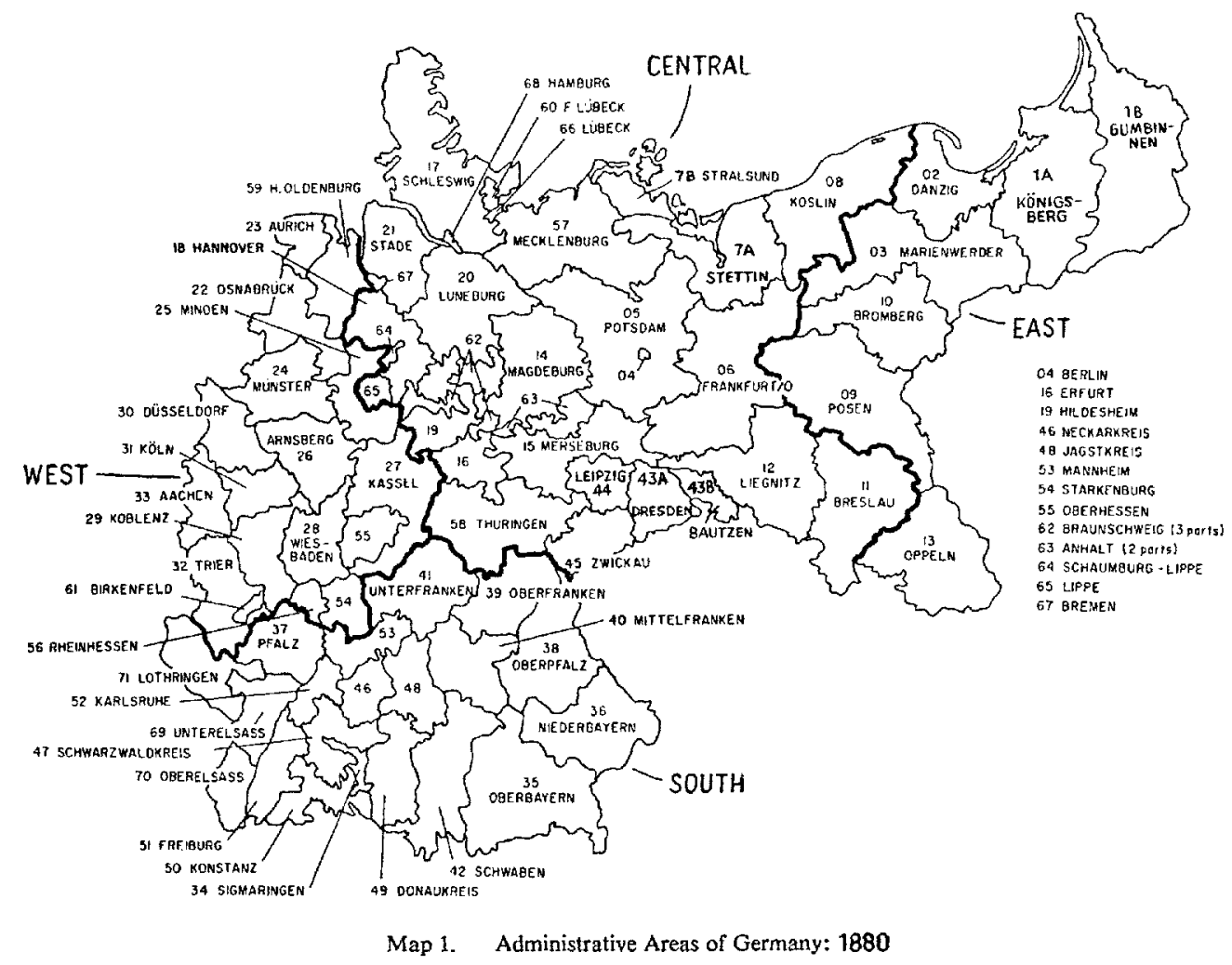

ous, since the areas included represent over 90 percent of the German population at the time.

The data for rural and urban segments of administrative areas are not uniformly comparable because they originate from independent publications of the individual state statistical offices, which enjoyed substantial autonomy, each utilizing its own scheme of urban-rural classification. Essentially two types of systems were used: one classified municipalities as rural or urban according to population size; the other was based on the legal status of a municipality. Some of the problems with each of these systems have been discussed elsewhere (Knodel, 1974:89-93; Weber, 1899). It is clear that the lack of a uniform

which there is no rural component; data for Mecklenburg is available only for MecklenburgSchwerin; data for Thüringen excludes SachsenMeiningen and Sachsen-Coburg-Gotha; the large unit is the state of Baden. definition of rural and urban subdivisions counsels caution when interpreting urbanrural differentials in demographic behavior. ${ }^{8}$

Additional data are available for all individual Prussian cities with a popula-

${ }^{3}$ A special study is done by the Oldenburg Statistical Bureau (1874:30) compared the two schemes in terms of the population each would define as urban or rural in $\mathbf{1 8 7 1}$ for a number of German states and Prussian provinces. According to the numerical principle used, an urban community was one of at least 2000 inhabitants; all others were rural. In seven of the twenty-three areas listed (including the three parts of the Grand Duchy of Oldenburg) the percent of the total population designated as urban by the two systems differed by less than one percent; in seven others the difference was five percent or less. The biggest disparities were found for two Prussian provinces: Rhineland, where 37 percent of the population lived in municipalities legally defined as cities compared to 57 percent living in municipalities with at least 2000 population, and Westphalia, where 28 percent lived in legally defined urban areas while 47 percent resided in places of 2000 or more inhabitants. 
tion of at least 20,000 since age-sex-marital status distributions were tabulated separately for them in the 1880 Prussian census volumes. Also all legally defined Bavarian cities regardless of population size were tabulated separately in the 1880 Bavarian census publications as were several individual cities in other states. These data help us in examining the influence of various urban settings on nuptiality.

\section{German Nuptiality Patterns}

On a national level in 1880 , Germany was characterized by late marriage and moderately substantial proportions remaining permanently single. The singulate mean age of marriage was 28.1 for men and 25.5 for women; the percent single at ages $45-49$ was 8.7 for men and $\mathbf{1 1 . 3}$ for women. This general pattern characterized Germany throughout the latter part of the nineteenth century and the early part of the twentieth century (Knodel, 1974: 68-70) and probably for a prolonged earlier period extending back perhaps for several centuries. ${ }^{9}$ Thus Germany as a whole clearly conforms to the uniquely "European" marriage pattern that characterized Northern and Western Europe for centuries as described by Hajnal (1965) in his pioneering article on the subject.

Within Germany, however, considerable differences in nuptiality patterns characterized different areas. The singulate mean age of marriage for men in 1880 ranged from just over 26 in the Saxon province of Zwickau to over 30 in the Westphalian area of Münster; for women the singulate mean age of marriage was below 24 in the Westphalian area of Arnsberg and well above 27 in the Rhineland area of Aachen. The proportion

${ }^{9}$ Although census data required for these calculations are not generally available for German states for even the first half of the nineteenth century, local population studies based on church records indicate a late age at marriage predominated as far back as such records extend (see e.g. Gaskin, 1975). remaining single at ages $45-49$ shows even more dramatic variation, ranging from 4.5 percent in the administrative area of Posen to 18 percent in Aachen for men in 1880 ; and from 5.6 percent in Zwickau to over 20 percent in Lower Bavaria (Niederbayern) for women. Such variations are not surprising considering the diverse economies, cultures, and historical traditions of the territories which had been joined together to form the German Empire barely a decade earlier.

Maps 2-5 illustrate regional patterns in the singulate mean age at marriage and in the proportions never-marrying for both men and women. ${ }^{10}$ Two broad areas of relatively early male marriage are apparent. The first is in the East and includes East and West Prussia, Posen, and Lower Silesia. The second includes the central German states of Saxony, Anhalt, and Thiïringen, and extends westward into Hesse. Late marriage of men was the characteristic pattern in Bavaria, particularly southern Bavaria and in the string of administrative areas forming the western border of the Empire. While there is an overall similarity between male and female age at marriage (the correlation between male and female singulate mean ages at marriage at the level of administrative area is .63), the regional pattern of age at marriage is not as striking for women as for men. Women were marrying late in the West and South; again, this was particularly true in southern Bavaria and in the Western border districts. But late marriage of women was also the trend in East Prussia, Pomerania, and Upper Silesia. Districts of early female marriage cluster into two regions: the first includes Saxony, Thüringen, Anhalt, and Braunschewig and extends south into Baden and westward into Hesse and Westphalia; the second, on the eastern border, includes Posen and part of West Prussia.

\footnotetext{
${ }^{10}$ The maps are based on the data summarized in Appendix Table A1.
} 

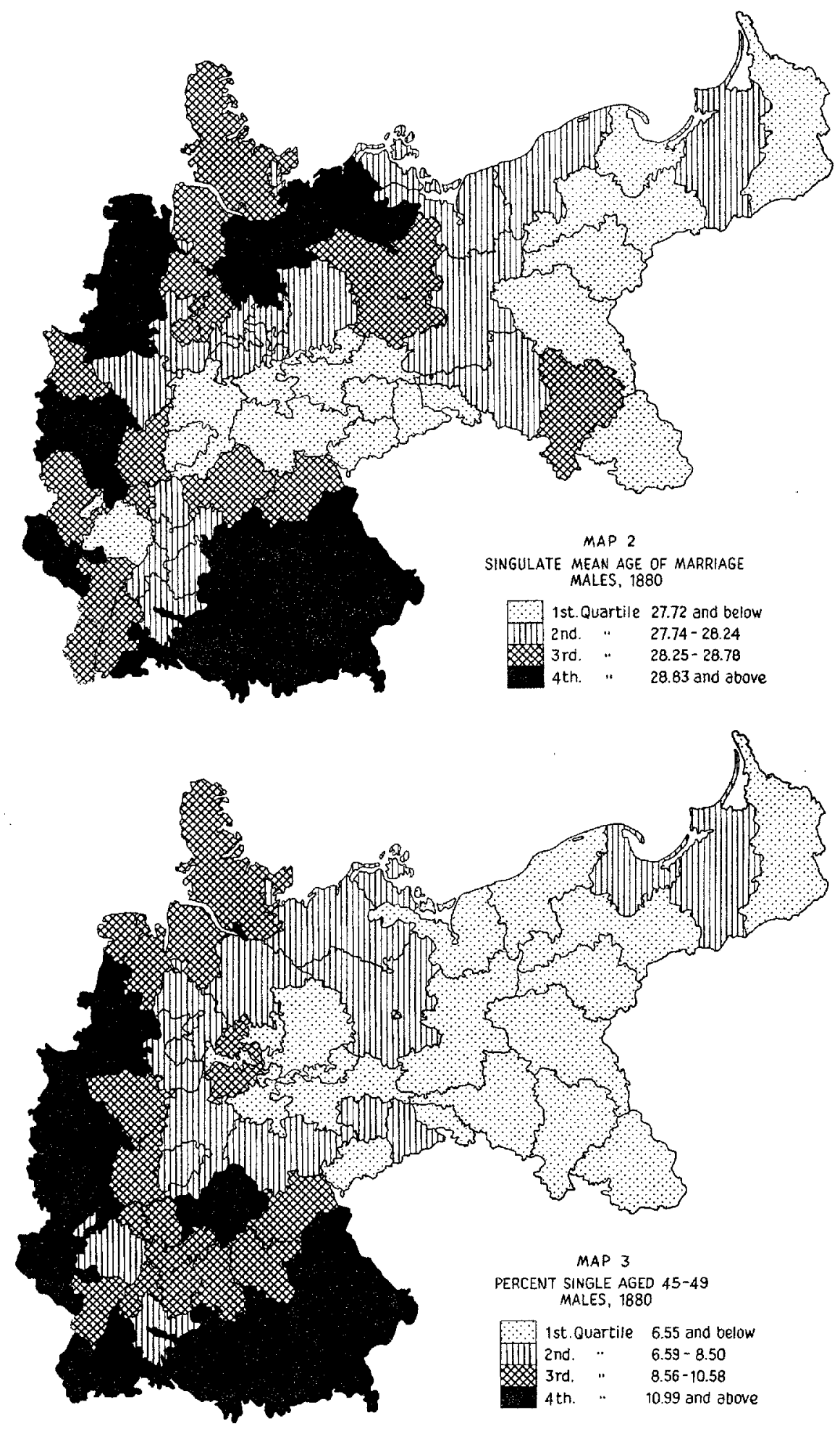

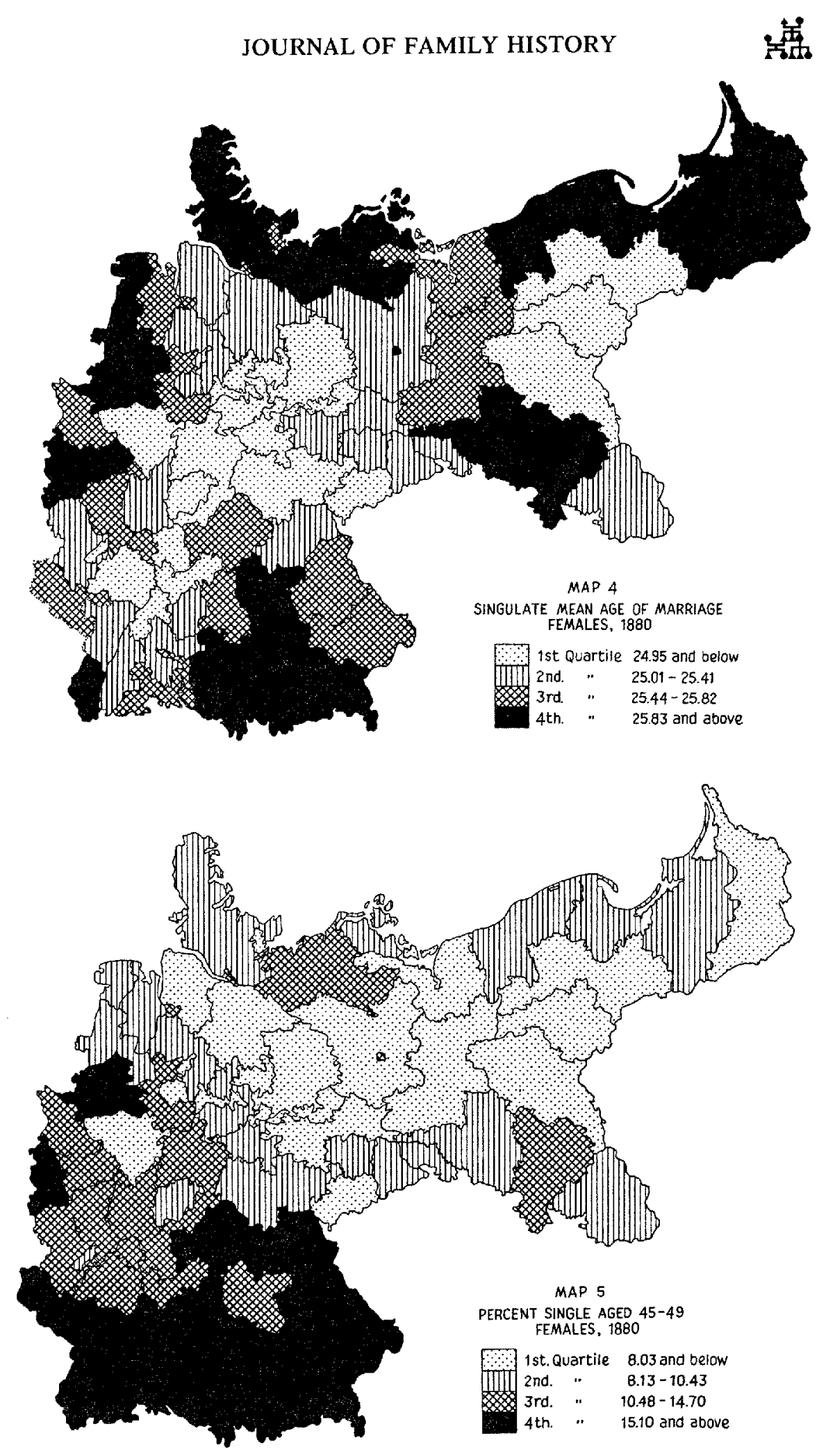
As for the proportion of the population who never marry, patterns emerge which are even more distinctly regional. The whole of eastern and central Germany was characterized by relatively low male celibacy. In the West and South higher rates of male celibacy were the norm; the highest concentrations of middle-aged bachelors were found in Southern Bavaria and Baden and in the Rhineland. Female celibacy rates correlate highly with male rates; at the level of administrative area, the correlation is .79 . Female celibacy was also well below average in eastern and central Germany. Generally it was close to the male rate, with the exception of Silesia and East Prussia, where slightly higher female rates prevailed. High rates of female celibacy are strikingly concentrated in the South-in Bavaria, Baden, and Alsace-Lorraine-and in a few Rhineland districts. ${ }^{11}$

It should be noted that these regional trends further substantiate Hajnal's claim that there is a distinct Western European marriage pattern characterized by late marriage and high celibacy. High extremes in both celibacy and age at marriage tend to characterize the westernmost regions of the German Empire. The extreme eastern region, and in particular those districts having large Polish populations-Posen, Bromberg, Oppeln, and

\footnotetext{
${ }^{11}$ Differences in nuptiality patterns between administrative areas were reasonably stable for both sexes in the last decades of the nineteenth century and for men even persisted relatively unchanged through the interwar years. The singulate mean age of marriage for men in the various administrative areas in 1880 correlates .84 with the 1900 values and .60 with the 1933 values; the proportions single among men 45-49 shows even closer agreement with the 1880 values correlating .93 with the 1900 values and .78 with the 1933 values. Marriage patterns for women show a somewhat lower temporal consistency for the singulate mean age of marriage, which correlates .60 between 1880 and 1900 and only .28 between 1880 and 1933; the proportion of women who were still single at ages $45-49$ in 1880 correlates .90 with $1900(\mathrm{~N}=14)$ values and .79 with $1933(\mathrm{~N}=66)$ values.
}

Marienwerder-usually fall in the lowest quartile for each nuptiality measure, suggesting, perhaps, a demographic border area in the east. A recent article exploring Eastern Europe marriage patterns (Sklar, 1974) suggests that this region is, in fact, closer to the "Western" than the "Eastern" pattern as described by Hajnal. Nonetheless, the East-West contrast is clear within Germany and these eastern provinces may form the beginning of a transition zone.

Because of the prominence of regional differences in some aspects of nuptiality, it will be useful to control for regional location in our analysis on urban-rural marriage patterns. In order to summarize regional patterns statistically, we have divided Germany into four regional clusters which we call, for simplicity, East, Central, West, and South (designated by broad outlines on Map 1). To some extent the boundaries are arbitrary as must be any division of Germany into regions on the basis of administrative area units. In at least a very crude manner however, they conform to some conventional political or cultural boundaries. The East region contains the seven administrative areas which formed the Prussian provinces of East and West Prussia, Posen, and Upper Silesia. All of these areas contained substantial numbers of non-German ethnic groups, especially Polish and Masurian (Knodel, 1974: 141-142). The South region includes Bavaria, Baden, Wirttemberg, AlsaceLorraine, and Sigmaringen, a Prussian enclave in Southern Württemberg, and corresponds to the conventional notion of southern Germany. The West region consists of Oldenburg, Hesse, the Prussian Province of Rheinland, Westphalia, and Hesse-Nassau, as well as Aurich and Osnabrück, the westernmost administrative areas of the Prussian province of Hannover. The remaining administrative areas form the Central region, separating the 
overwhelmingly Protestent central areas from the religiously mixed industrialized Rhine and Ruhr valleys in the West. ${ }^{12}$

Table 2 shows the regional means for both proportion single at ages $45-49$ and the singulate mean age at marriage for both sexes. The high rates of celibacy for both men and women in the South followed closely by the West region, and the much lower proportions remaining celibate in the East followed closely by the Central region, are clearly evident. The ages of marriage for women are virtually identical for all regions but differ somewhat for men with the youngest average age characterizing the East and the oldest characterizing the South. The correlation ratio $\left(E^{2}\right)$ which expresses the ratio of between-region-variation to total variation for each nuptiality measure indicates that the degree of association between the regional location and the

TABLE 2. PERCENT SINGLE AGED 45-49 AND SINGULATE MEAN AGE AT MARRIAGE BY SEX AND REGION, 1880

\begin{tabular}{lccccc}
\hline \hline \multirow{2}{*}{$\begin{array}{c}\text { Dependent } \\
\text { Variable: }\end{array}$} & \multicolumn{5}{c}{ Region } \\
\cline { 2 - 5 } & East & Central & West & South & $E^{2}$ \\
\hline $\begin{array}{c}\text { PS 45-49, } \\
\text { men }\end{array}$ & 5.7 & 7.2 & 10.3 & 11.5 & $.466^{\mathrm{a}}$ \\
$\begin{array}{c}\text { PS 45-49, } \\
\text { women }\end{array}$ & 7.9 & 8.7 & 11.8 & 16.7 & $.720^{\mathrm{a}}$ \\
$\begin{array}{c}\text { SMAM, } \\
\text { men }\end{array}$ & 27.4 & 28.0 & 28.6 & 28.8 & $.308^{\mathrm{a}}$ \\
$\begin{array}{c}\text { SMAM, } \\
\text { women }\end{array}$ & 25.5 & 25.4 & 25.6 & 25.5 & .009 \\
$\begin{array}{c}\text { Number of } \\
\text { areas }\end{array}$ & 7 & 30 & 17 & 20 & \\
\hline
\end{tabular}

Notes: PS $45-49=$ Percent single aged 45-49; SMAM $=$ singulate mean age at marriage.

$E^{2}=$ Correlation ratio (between sum of squares/ total sum of squares).

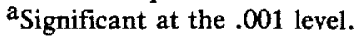

${ }^{12}$ The regional groupings used in the present study are not identical with those used in Knodel, (1974). Since the number of administrative areas with urban-rural nuptiality data is substantially below the total number, a broader regional classification was more appropriate. nuptiality measures range from virtually no association for the singulate mean age at marriage for women to a very strong association for female celibacy. ${ }^{13}$

${ }^{13}$ Anyone familiar with the geographical distributions of the German population by religious affiliation will recognize from Maps 2-5 that areas with unusually high proportions single at ages 45.49 for both men and women are in most cases predominately Catholic. The overall correlation between percent Catholic and the proportion single $45-49$ for all German administrative areas is .68 for men and .70 for women. The singulate mean age of marriage also shows some association with the religious composition of the administrative areas although a much weaker one, correlating . 47 with percent Catholic for males and only .23 for women.

Although to some extent the regional patterns of nuptiality may be a function of religious composition, regional consistency transcends differences in religious composition in a number of instances. For example, throughout the easternmost areas of the empire including predominantly Catholic Upper Silesia (Oppeln) as well as half-Catholic Bromberg and Marienwerder the proportion single among men 45-49 was uniformly low; in the largely Protestant parts of Wurttemberg in southern Germany, on the other hand, the proportion single among women 45-49 is uniformly high.

Together the percent Catholic and regional location account for much of the total variation in the nuptiality measures. An analysis of covariance indicates that both regional location and percent Catholic exert independent influences on the percent never marrying for both sexes and the male age at marriage. The female age at marriage shows little relationship with either.

The association between religious composition and nuptiality based on the administrative area as the unit of analysis do not necessarily mean that Protestants and Catholics within the same area differ in their marriage patterns; nor does it mean that if there are religious differentials in nuptiality within an area that the Catholies necessarily marry later or less. Data for direct comparisons between Protestant and Catholic marriage patterns within the same administrative area are rarely available for Germany in the nineteenth century. Some evidence for Berlin and Munich suggest that in those cities the difference between Catholics and Protestants with regard to the singulate mean age of martiage and proportions marrying by the end of the marriageable ages were neither large nor even necessarily in the expected direction. 


\section{Urban-Rural Differences in Marriage Patterns}

The complete set of nuptiality measures for the 61 German administrative areas with separate data available by rural and urban residence categories for 1880 are presented in Appendix Table A2. To the best of our knowledge, this covers all cases where the requisite data are available. These data, summarized in Table 3, permit us to assess general patterns of urban-rural differentials in our measures at the administrative area level.

The overall thrust of our results is clear: the proportions never marrying and the singulate mean age at marriage were typically higher in the urban areas and lower in the countryside. The results are most striking for the proportion single aged 45-49. The urban areas are characterized by high levels of female celibacy in all but one case (the urban sector of the city state of Hamburg compared to the rural sector). In over 90 percent of the areas the percent of women remaining permanently single was at least two percentage points higher in the urban than the rural areas. In a substantial majority of areas, male celibacy was also higher in urban areas although typically the urbanrural difference for males was minimal (less than two percentage points). The singulate mean age at marriage was also generally higher in the cities and in about half the areas the urban average exceeded the rural average by a quarter of a year.

The simple urban-rural dichotomy utilized so far is extremely crude and may mask important differences within each category. Since "urban" communities as defined by the various German statistical bureaus typically included a wide variety of urban places ranging from small towns, sometimes with less than 2000 inhabitants, to large cities with upward of 100,000 inhabitants, it is important to subdivide this category whenever possible to investigate if nuptiality in large cities differed from that in the smaller towns. Is there a rough continuum in marriage patterns that runs from rural villages to large cities with the towns occupying an intermediate position? Were residents of towns closer in their nuptiality habits to their counterparts in villages or cities? The data for Germany help provide answers to these questions.

TABLE 3. DISTRIBUTION OF URBAN-RURAL DIFFERENCES IN NUPTIALITY MEASURES IN GERMAN ADMINISTRATIVE AREAS, 1880

\begin{tabular}{lrrrr}
\hline & \multicolumn{2}{c}{ Men } & \multicolumn{2}{c}{ Women } \\
\cline { 2 - 5 } & \multicolumn{1}{c}{$\%$} & $\mathrm{~N}$ & $\%$ & $\mathrm{~N}$ \\
\hline Proportion single 45-49 & 1.6 & 1 & 42.6 & 26 \\
\hline Urban > rural by 5\% or more & 19.7 & 12 & 49.2 & 30 \\
Urban > rural by 2.0-4.9\% & 49.2 & 30 & 6.6 & 4 \\
Urban > rural by less than 2\% & 19.7 & 12 & 1.6 & 1 \\
Rural > urban by less than 2\% & 8.2 & 5 & 0.0 & 0 \\
Rural > urban by 2.0-4.9\% & 1.6 & 1 & 0.0 & 0 \\
Rural > urban by 5\% or more & 100 & 61 & 100 & 61 \\
All areas & & & & \\
Singulate mean age at marriage & 19.7 & 12 & 21.3 & 13 \\
Urban > rural by 1 year or more & 36.1 & 22 & 29.5 & 18 \\
Urban > rural by .25..99 years & 19.7 & 12 & 13.1 & 8 \\
Urban > rural by less than .25 years & 16.4 & 10 & $9.8^{\mathrm{a}}$ & $6^{\mathrm{a}}$ \\
Rural > urban by less than .25 years & 3.3 & 2 & 19.7 & 12 \\
Rural > urban by .25-.99 years & 4.9 & 3 & 6.6 & 4 \\
Rural > urban by 1 year or more & 100 & 61 & 100 & 61 \\
All areas & & & & \\
\hline
\end{tabular}

Notes: Based on Appendix Table A2.

${ }^{a}$ Including one case where rural and urban values were equal. 
For 42 of the administrative areas included in Appendix Table A2, it is possible to divide the overall urban category into towns and cities when calculating the nuptiality indices. Although a uniform dividing line cannot be used everywhere, in most cases urban areas with less than 20,000 inhabitants were classified as towns and those with at least 20,000 as cities. Table 4 summarizes how our nuptiality variables compared in cities, towns, and rural areas of these 42 administrative areas. Clearly the most common pattern was for age of marriage and celibacy to be greatest in the cities and least in the countryside with the towns occupying an intermediate position. In two-thirds of the areas the proportion of women remaining permanently celibate followed this progression. For men remaining single, this was the case in almost half of the areas. In somewhat less than half the administrative areas, the singulate mean age of marriage of either sex was highest in the cities and lowest in the rural communities. Focusing on the two urban categories, in a substantial majority of areas marriage was later and celibacy more common in cities than in towns.

In order to determine if the marriage patterns in towns resembled more closely those of the larger cities or those of the rural areas, we turn to correlational analysis. Table 5 presents the results.
Because most of the nuptiality measures, regardless of the urban-rural category, varied substantially with the regional location of the administrative areas, results are presented both statistically adjusted and unadjusted for this factor. ${ }^{14}$

For three of our measures-the male SMAM and proportions remaining single for men and women-the unadjusted results indicate a substantially higher correlation between rural and small city sectors within the same administrative areas than there is between the measures for large cities and those for the other two residence categories. For female SMAM, small cities' measures correlate about equally with those of rural areas and large cities. For the adjusted results, correlations for all four measures are higher between towns and rural areas than between cities and either of these categories. This suggests that marital

${ }^{14}$ The adjustment was achieved by partial correlation using regional location as a control variable. More exactly, three dummy variables were created, one for presence or absence in each of three of the four regions (it makes no difference which three of the four were chosen) and a partial correlation was calculated between the two main variables simultaneously controlling for the three dummy variables. For an explanation of this technique see $\mathrm{Nie}$, et. al., (1975:373-383). In effect the result represents the correlation between the deviation of the two main variables from their regional means and thus is the average "within region correlation" weighted by the number of cases in each region.

TABLE 4. DISTRIBUTION OF GERMAN ADMINISTRATIVE AREAS ACCORDING TO A COMPARISON OF NUPTIALITY MEASURES IN CITIES, TOWNS, AND RURAL AREAS, 1880

\begin{tabular}{|c|c|c|c|c|}
\hline & \multicolumn{2}{|c|}{$\begin{array}{l}\text { Percent single } \\
\text { aged } 45-49\end{array}$} & \multicolumn{2}{|c|}{$\begin{array}{l}\text { Singulate mean age } \\
\text { at marriage }\end{array}$} \\
\hline & Men & Women & Men & Women \\
\hline $\begin{array}{l}\text { Cities }>\text { towns }>\text { rural } \\
\text { Towns }>\text { cities }>\text { rural } \\
\text { Cities }>\text { rural }>\text { towns } \\
\text { Towns }>\text { rural }>\text { cities } \\
\text { Rural }>\text { cities }>\text { towns } \\
\text { Rural }>\text { towns }>\text { cities }\end{array}$ & $\begin{array}{r}19 \\
5 \\
4 \\
8 \\
3 \\
3\end{array}$ & $\begin{array}{r}16 \\
2 \\
11 \\
4 \\
6 \\
3\end{array}$ & $\begin{array}{l}18 \\
7 \\
3 \\
4 \\
6^{a} \\
4\end{array}$ & $\begin{array}{r}28 \\
8 \\
2 \\
4 \\
0 \\
0\end{array}$ \\
\hline Number of areas & 42 & 42 & 42 & 42 \\
\hline
\end{tabular}

Notes: Based on Table A2.

${ }^{a}$ Includes one case where rural $>$ cities $=$ towns. 
TABLE 5. CORRELATIONS BETWEEN URBAN-RURAL CATEGORIES FOR PROPORTIONS SINGLE IN AGES 45-49 AND SMAM BY SEX, GERMAN ADMINISTRATIVE AREAS, 1880

\begin{tabular}{|c|c|c|c|c|}
\hline & \multicolumn{2}{|c|}{$\begin{array}{c}\text { Percent single } \\
\text { aged } 45-49\end{array}$} & \multicolumn{2}{|c|}{$\begin{array}{c}\text { Singulate mean age } \\
\text { at marriage }\end{array}$} \\
\hline & Men & Women & Men & Women \\
\hline \multicolumn{5}{|c|}{ Unadjusted for regional location } \\
\hline Rural with towns & .884 & .889 & .696 & .635 \\
\hline Towns with cities & .648 & .659 & .604 & .666 \\
\hline Rural with cities & .652 & .682 & .417 & .371 \\
\hline \multicolumn{5}{|c|}{ Adjusted for regional location ${ }^{a}$} \\
\hline Rural with towns & .749 & .731 & .692 & .819 \\
\hline Towns with cities & .489 & .530 & .514 & .602 \\
\hline Rural with cities & .493 & .630 & .474 & .543 \\
\hline
\end{tabular}

Note: All correlation coefficients are based on $\mathbf{4 2}$ administrative areas.

a Correlations of deviations from regional means.

behavior in large cities was somewhat distinct.

Further evidence to this effect can be found in the analysis of nuptiality measures according to city size. Since detailed census data on age, sex, and marital status are available for 1880 for individual cities in Prussia with a population of at least 20,000 and for all officially designated cities in Bavaria regardless of size, it is possible to calculate the average value of our nuptiality measures for different size categories of cities (the complete set of nuptiality measures for the individual cities are provided in Appendix Tables A3 and A4). The results, presented in Table 6 , indicate that for both Prussia and Bavaria the main distinction in terms of nuptiality patterns within the urban category was between the largest urban categories (cities with populat:ons of at least 100,000 ) and all other cities and towns. Apparently it was in the large metropolitan centers that people were marrying the latest and celibacy was most common. Among the cities with population under 100,000 , no systematic relationship between the pro-

TABLE 6. NUPTIALITY MEASURES BY CITY SIZE, PRUSSIA AND BAVARIA, 1880

\begin{tabular}{|c|c|c|c|c|c|}
\hline \multirow[b]{2}{*}{ State and City Size } & \multicolumn{2}{|c|}{$\begin{array}{l}\text { Percent single } \\
\text { aged 15-49 }\end{array}$} & \multicolumn{2}{|c|}{$\begin{array}{l}\text { Singulate mean age } \\
\text { at marriage }\end{array}$} & \multirow{2}{*}{$\begin{array}{l}\text { Number of cities } \\
\text { (or areas) }\end{array}$} \\
\hline & Men & Women & Men & Women & \\
\hline \multicolumn{6}{|l|}{ Prussia: } \\
\hline Cities $100,000+$ & 10.0 & 16.0 & 28.76 & 26.85 & 7 \\
\hline Cities $50,000-99,999$ & 8.4 & 12.6 & 28.14 & 25.63 & 17 \\
\hline Cities $20,000-49,999$ & 8.7 & 12.0 & 28.08 & 25.42 & 45 \\
\hline Urban under $20,000^{\mathrm{a}}$ & 8.8 & 12.0 & 28.37 & 25.72 & $35^{\mathrm{c}}$ \\
\hline Rural $^{b}$ & 8.1 & 8.3 & 28.07 & 25.49 & $35^{\mathrm{c}}$ \\
\hline \multicolumn{6}{|l|}{ Bavaria: } \\
\hline Cities $100,000+$ & 15.4 & 21.7 & 30.06 & 26.46 & 1 \\
\hline Cities $50,000-99,999$ & 9.4 & 17.5 & 28.77 & 25.59 & 4 \\
\hline Cities $20,000-49,999$ & 9.9 & 17.8 & 28.42 & 25.62 & 6 \\
\hline Cities, under 20,000 & 11.4 & 19.4 & 29.28 & 25.43 & 38 \\
\hline Rural $^{b}$ & 12.1 & 15.5 & 28.82 & 25.52 & $8^{c}$ \\
\hline
\end{tabular}

Notes: Results are based on the means of the individual city values unweighted by size of population except as noted.

aBased on the unweighted average of "Town" category for the 35 Prussian administrative areas with this category and therefore differs from figures given in Table 1 .

based on the unweighted average of the "Rural" category for the separate administrative areas with this category and therefore differs from figures given in Table 1 .

${ }^{{ }^{2}}$ Number of administrative areas used to calculate unweighted averages. 
portion single and city size is evident. Nuptiality levels in the rural areas were generally closer to those in the cities under 100,000 than to those in the large cities.

It is worth pointing out that although the predominant pattern in Germany was of higher celibacy and older ages at marriage in the urban areas, it is also true that the average urban-rural difference was not large. In areas where the rural age of marriage was late or the rural level of celibacy was high, the same was typically true of the urban areas as seen in the correlation between rural and urban values of the nuptiality measures. The proportion single $45-49$ correlated .82 between rural and urban populations of the same administrative area for men and .86 for women; the correlation between the rural and urban SMAM was .68 for men and .52 for women.

There is also a geographic pattern to the urban-rural difference in nuptiality. Eight of the 15 areas in which men were marrying earlier in the city are located in the West region (especially in the Rheinland and Westphalia); the rest are scattered through Bavaria and central Germany. The areas where male celibacy was lower in the cities were also disproportionately concentrated in western administrative areas. A somewhat similar pattern in terms of age of marriage is apparent for women: areas of earlier urban than rural marriage predominate among the westernmost and northwestern administrative areas with the remainder largely in Bavaria and central Germany. Urban-rural differences in the singulate mean age at marriage correlate .66 between males and females for the 61 administrative areas, reflecting the similarity in the geographic pattern of urban-rural differences for both sexes.

Table 7 summarizes the regional differences in rural and urban nuptiality. The correlation ratio $\left(E^{2}\right)$ indicates a strong association between regional location and rural and urban celibacy rates for both sexes. The SMAM for rural and urban

TABLE 7. URBAN, RURAL, AND URBAN-RURAL DIFFERENCES FOR PROPORTIONS SINGLE AGED 45-49 AND SINGULATE MEAN AGE AT MARRIAGE BY SEX AND REGION, GERMAN AD. MINISTRATIVE AREAS, 1880

\begin{tabular}{|c|c|c|c|c|c|c|}
\hline \multirow[b]{2}{*}{ Measure and residence category: } & \multirow[b]{2}{*}{ All Areas } & \multicolumn{4}{|c|}{ Region } & \multirow[b]{2}{*}{$\mathbf{E}^{2}$} \\
\hline & & East & Central & West & South & \\
\hline \multicolumn{7}{|l|}{ Proportion single 45.49 , men } \\
\hline Urban & 9.1 & 7.2 & 8.0 & 10.0 & 11.9 & $.374^{\mathrm{d}}$ \\
\hline Rural & 8.5 & 5.2 & 6.7 & 10.5 & 12.1 & $.511^{\mathrm{d}}$ \\
\hline Urban-rural & 0.6 & 2.0 & 1.3 & -0.5 & -0.1 & $.219^{\mathrm{c}}$ \\
\hline \multicolumn{7}{|l|}{ Proportion single 45-49, women } \\
\hline Urban & 14.1 & 11.9 & 11.2 & 15.9 & 20.7 & $.562^{\mathrm{d}}$ \\
\hline Rural & 9.3 & 6.4 & 7.1 & 10.1 & 15.9 & $.719^{\mathrm{d}}$ \\
\hline Urban-rural & 4.8 & 5.4 & 4.1 & 5.8 & 4.8 & .097 \\
\hline \multicolumn{7}{|l|}{ Singulate mean age at marriage, men } \\
\hline Urban & 28.45 & 28.41 & 28.15 & 28.48 & 29.27 & $.302^{\mathrm{d}}$ \\
\hline Rural & 28.03 & 26.96 & 27.69 & 28.56 & 28.77 & $.377^{\mathrm{d}}$ \\
\hline Urban-rural & 0.41 & 1.45 & 0.43 & -0.09 & 0.50 & $.388^{\mathrm{d}}$ \\
\hline \multicolumn{7}{|c|}{ Singulate mean age at marriage, women } \\
\hline Urban & 25.68 & 26.63 & 25.49 & 25.45 & 25.75 & $.204^{\mathrm{c}}$ \\
\hline Rural & 25.34 & 25.04 & 25.28 & 25.49 & 25.45 & .028 \\
\hline Urban-rural & 0.32 & 1.59 & 0.17 & 0.05 & 0.31 & $.336^{\mathrm{d}}$ \\
\hline Number of areas & $61^{\mathrm{a}}$ & 7 & $27^{\mathrm{b}}$ & 17 & 10 & \\
\hline
\end{tabular}

Notes: The urban category includes Berlin for which there is no rural counterpart.

$a_{62}$ for urban which includes Berlin.

$\mathrm{b}_{28}$ for urban which includes Berlin.

'Significant at the .01 level.

$\mathrm{d}_{\text {Significant at the } .001 \text { level. }}$ 
men and urban women show a moderate association with regional location. Only the age of marriage for rural women appears to show no distinct regional pattern. There is also a moderate association between regional location and urban-rural differences for all the nuptiality measures except female celibacy which is uniformly higher in the urban areas than in rural areas for all regions. The largest urban-rural differences in both male and female age at marriage and in male celibacy are found in the East.

While we are not attempting here to analyze regional phenomena, a few possible components of the Eastern pattern of relatively high urban-rural differences in nuptiality suggest themselves. Without direct data on ethnic differentials in nuptiality no firm conclusion can be reached concerning the contribution of non-German ethnic groups to this result but it is worth noting that the cities in this region tended to have higher concentrations of ethnic Germans than the countryside. If the non-Germans were closer to the Eastern European marriage pattern described by Hajnal (1965) and Sklar (1974) than their German counterparts, this could help explain why the urban-rural differentials in the East region were more pronounced than elsewhere. Furthermore, the large eastern cities tended to be administrative centers. As such, their occupational structures were different from those of cities in other regions, whose populations were more likely to include larger commercial or industrial sectors. Clearly urban occupational structures were closely related to factors of extreme importance for nuptiality such as migration patterns and sex ratios.

\section{Servants, Soldiers, and Sex Ratios}

Perhaps more so than in any time in the past, the nature of the rural and urban populations in late nineteenth-century
Germany was being shaped and transformed by massive streams of migrants leaving the countryside for new homes in the cities. At the same time, significant migratory exchanges were occurring between cities as well. Substantial proportions of adults in towns and cities of all sizes had been born and raised elsewhere, usually in rural areas (c.f. Wirminghaus, 1895:165). ${ }^{15}$ Although the impact of these migratory flows must have been felt in virtually all spheres of life, our interest focuses on the effects on marriage. Migration patterns both responded to marriage possibilities and helped mold them. Indeed, the interrelationships between migration and nuptiality are complex and difficult, if not impossible, to disentangle completely.

Closely related to migration patterns is the whole question of job opportunities and the relationship between the types of employment drawing people to cities and marital possibilities there. As urbanization progressed, more and more people were being channeled into urban forms of employment. Occupational structures were clearly different in cities than in rural areas; within cities, natives and rural migrants often worked at different jobs. Furthermore, industrial cities attracted different types of migrants from those who went to administrative centers or mining towns. Since employment was generally sex-typed, it was often the case that migrants to or from a region were predominantly of one sex. Generally women were more likely to migrate than men, but mainly over shorter distances; for women, migration was frequently linked directly to marriage or to the demand for domestic servants in provincial towns and cities while men were more likely to go longer distances in response to

's For a useful discussion of internal migration and its relationship to urbanization during the nineteenth century both in Germany and elsewhere see Weber (1899: Chapter IV); see also Brückner (1890). 
TABLE 8. PERCENT SINGLE BY MILITARY STATUS AND AGE, AGE DISTRIBUTION OF MILITARY POPULATION, AND PERCENT IN MILITARY-BAVARIAN MEN, 1880

\begin{tabular}{crrrrr}
\hline & \multicolumn{3}{c}{$\%$ Single } & $\begin{array}{c}\text { \% Of military 15-49 } \\
\text { in each age group }\end{array}$ & \% Of men in military \\
\cline { 2 - 6 } Age & Civil & Military & Total & 3.9 & 0.8 \\
$15-19$ & 100.0 & 100.0 & 100.0 & 86.0 & 19.1 \\
$20-24$ & 93.1 & 99.9 & 94.4 & 4.9 & 1.2 \\
$25-29$ & 60.8 & 81.9 & 61.1 & 2.2 & 0.6 \\
$30-34$ & 31.3 & 44.7 & 31.3 & 1.2 & 0.3 \\
$35-39$ & 18.2 & 27.5 & 18.3 & 1.1 & 0.3 \\
$40-44$ & 14.3 & 16.6 & 14.3 & 0.7 & 3.7 \\
$45-49$ & 12.5 & 12.7 & 12.5 & 100.0 & \\
$15-49$ & 51.2 & 95.3 & 52.8 & & \\
\hline
\end{tabular}

modern labor market conditions (Weber, 1899:276-280). Such movements undoubtedly influenced marital possibilities both in the areas to which the migrants went and in the ones they left.

Two easily identifiable urban groupings of young people-soldiers and household servants-consisted of large numbers of single men and women in their twenties who came from rural origins and were drawn into urban concentrations. The impact that these two special categories had on the demographic structure of cities can serve as an illustration of the relationship between migration, urban employment, and nuptiality.

The presence of a military garrison in a city could seriously affect the age structure and sex ratio of the urban population. Because of the nature of the conscription system, most German soldiers were between the ages of 20 and 25 and were unmarried. For example, around 1880, 82 percent of all soldiers were aged 20-24 (Brückner, 1890: 652) and 98 percent of all soldiers under the age of 30 were single (Kollmann, 1890:602). Since the 1880 Bavarian Census tabulated the military and civilian male population separately with regard to age and marital status, a direct comparison between these two groups is possible with respect to the proportion single. As indicated in Table 8, military men were more likely than civilians to be single at every age. However, since soldiers were concentrated predominately in the 20.24 age group and it is only for these ages that they represent a substantial proportion of men, they can have little impact on the proportion single at other ages. Even for the 20-24 age group, the impact is limited since so few men, civilian or military, married before age 25 .

Of primary concern for our discussion of urban-rural differences in marriage patterns is the fact that the military population was limited largely to urban areas; for some small cities, the garrison population could represent a very significant proportion of all men. Table 9 presents both the distribution of the military population in Bavaria and its relative impact upon the male proportion single. Only a few percent of men aged 20-24 residing in rural areas were in the military while over half of those in smaller cities and over a third living in the larger ones were. ${ }^{16}$ Among the individual cities,

${ }^{16}$ Similarly in Prussia, the military population was limited to urban areas. Although age data on the military population by rural-urban residence are lacking in the 1880 Prussia Census, figures on the total military population are available. Since the proportion of soldiers who were 20.24 is so high, a rough index of the proportion of this age group in the military can be achieved by relating the entire military population to men 20-24. Of course this overestimates the percent of men 20-24 in the military but provides a fairly accurate relative index as indicated by the fact that among the 49 Bavarian cities, for which both the ratio of the total military population to men 20-24 and the actual proportion of men $20-24$ that were soldiers 
TABLE 9. PERCENT OF MEN 20-24 IN MILITARY AND MALE NUPTIALITY MEASURES FOR THE CIVILIAN AND TOTAL POPULATION BY URBAN-RURAL RESIDENCE-BAVARIA, 1880

\begin{tabular}{|c|c|c|c|c|c|c|c|}
\hline & \multirow{2}{*}{$\begin{array}{l}\% \text { Of all men } \\
\text { aged } 20-24 \\
\text { in military }\end{array}$} & \multicolumn{2}{|c|}{$\%$ Single $20-24$} & \multicolumn{2}{|c|}{$\%$ Single $25-29$} & \multicolumn{2}{|c|}{ SMAM } \\
\hline & & Civil & Total & Civil & Total & Civil & Total \\
\hline $\begin{array}{l}\text { Cities } 20,000+ \\
\text { Cities under } 20,000 \\
\text { Rural }\end{array}$ & $\begin{array}{r}37.0 \\
56.7 \\
6.6\end{array}$ & $\begin{array}{l}94.1 \\
92.3 \\
93.0\end{array}$ & $\begin{array}{l}96.3 \\
96.6 \\
93.4\end{array}$ & $\begin{array}{l}62.6 \\
59.0 \\
60.6\end{array}$ & $\begin{array}{l}63.3 \\
60.2 \\
60.7\end{array}$ & $\begin{array}{l}29.26 \\
28.78 \\
28.77\end{array}$ & $\begin{array}{l}29.45 \\
29.12 \\
28.80\end{array}$ \\
\hline Total & 19.1 & 93.1 & 94.4 & 60.8 & 61.0 & 28.83 & 28.92 \\
\hline
\end{tabular}

however, there is no simple relationship between city size and percent of men in the military. For example, for both Bavarian and Prussian cities, correlations between city size (or the log of city size) and proportion of males in the military is virtually zero. The most striking feature among both large and small cities was the tremendous range of the proportion of young men in the military, a function not only of the differences in city population size but presumably even more so of the fact that not all cities had garrisons and the sizes of garrisons varied greatly. Thus in 17 of the 38 Bavarian cities with populations of fewer than 20,000 , less than five percent of the men $20-24$ were soldiers while in 6 others over three-fourths were. Likewise among the 11 Bavarian cities with populations exceeding 20,000 , the proportion of men 20-24 in the military ranged from less than five percent in five of them to more than half in three others. ${ }^{17}$

can be calculated, these two measures correlate almos perfectly (.998). The ratio of total military to men 20-24 for Prussia indicates the concentration of the military in the cities (figures for Bavaria using this same index are provided for comparison):

Cities $20,000+$

Cities under 20,000

Rural

Total

$\begin{array}{cc}\text { Prussia } & \text { Bavaria } \\ .478 & .452 \\ .374 & .661 \\ .028 & .074 \\ .218 & .223\end{array}$

\footnotetext{
17Data for Prussian cities also indicate a wide dispersion in the extent of the military population with many cities having virtually no military presence while in a few the total number of soldiers (of all ages) exceeded the size of the total male age group 20-24.
}

The Bavarian data presented in Table 9 indicate, as might be expected, that the impact which soldiers had on nuptiality was most evident in its effect on the percent single 20-24 and was most pronounced in the smaller cities. The inclusion of soldiers raises the percent single 20-24 in cities with less than 20,000 by over four percentage points. The effect in the larger cities is weaker, not so much because of the smaller percentage of soldiers but because of the greater tendency in these cities for civilian men also to be single in these ages. Almost no impact is noticeable for the rural population because soldiers constitute such a small proportion of the population. Little impact from the military is evident on the percent single 25-29 for any of the rural or urban residence categories since so few men in this age category are still in the military.

The impact of including the military population in the calculation of the singulate mean age at marriage is negligible for rural males. For men living in the small cities, however, the inclusion of soldiers raises the singulate mean age at marriage by about a third of a year; for men living in the larger cities the effect is somewhat weaker. For some individual cities of course the impact could be much greater. The extreme cases can serve as interesting illustrations. Where there were few soldiers, of course, civilian and total male singulate mean age at marriage were close to identical. In the small Palatinate city of Germersheim, however, where the proportion of men in the military was the 
highest in Bavaria (95 percent of men 20-24 and three-quarters of all men 15-49), the singulate mean age at marriage for all men was 1.25 years greater than for the civilians alone. ${ }^{18}$

The effect of the presence of garrisons on the singulate mean age of marriage should be viewed largely as a statistical distortion rather than as representing a genuine component of the marriage pattern. Migration connected with military service is generally temporary. The large majority of soldiers were recruited from outside the town in which they were garrisoned (Kuczynski, 1897:25-26) and presumably few remained there following discharge. ${ }^{19}$ Fortunately for most cities this distortion is not large. It is interesting to note from Table 9 that for Bavaria, the differences in the male percent single 20-24 and the SMAM between rural areas and small cities evident for the total population largely disappear when consideration is limited to the civilian population. The later marriage and higher percent single aged 20-24 in the large cities remain.

Table 10 presents the correlation coefficients between measures of the extent of military presence on the one hand and the percent single 20-24 and the singulate mean age at marriage on the other. For Prussian cities and administrative areas, where data for the total number

1s In Prussia, the direct effect of military presence cannot be ascertained but it is worth noting that the upper Silesian city of Neisse was characterized by both the highest ratio of military population to men 15-49 and the highest male singulate mean age at marriage (30.65) found for all 69 Prussian cities with populations of at least 20,000 .

${ }^{19}$ The drop in the proportion single between the age groups 20-24 and 25-29 in towns with garrisons which influences the calculation of the singulate mean age at marriage, is affected by the fact that the proportion single 20-24 is inflated by the presence of soldiers while for the 25-29 group soldiers have little impact. of soldiers is known but data for soldiers by age group are lacking, military presence was measured by relating the total military population both to the number of men 20-24 and to the number of men 15-49. A substantial amount of the variance in the percentage of men single in the 20-24 age group within Bavarian cities and within Prussian large cities can be accounted for by the proportion of men in the military. Weaker although not negligible correlations existed between these measures among the total urban sectors of Prussian administrative areas. In the Prussian and Bavarian cities the singulate mean age at marriage is also associated with military presence. However, the military presence has virtually no impact on either nuptiality measure in Prussian rural areas. Furthermore, while the existence of military garrisons in the cities appears to account for part of the urban-rural difference for Prussian administrative areas in the proportion of men who were single in their early 20 s, military concentration in the cities has little to do with urban-rural difference in the male SMAM as seen in the low correlation.

In general then, the fact that military conscription brought masses of single men into cities seems to have had some influence on nuptiality patterns in the smaller cities. Limited mainly to affecting the proportion single among men in their early $20 \mathrm{~s}$, however, military migration cannot go far in explaining overall urban-rural differences in marriage habits.

The impact of servants, on the other hand, seems to have been quite strong. Domestic service played a role of considerable significance in the early modern economy. Its importance as a source of employment, particularly for women, cannot be overemphasized. Though the sector was declining, it still included over a third of employed women in Prussia in 1882. The demographic 
TABLE 10. CORRELATION COEFFICIENTS BETWEEN MEASURES OF NUPTIALITY AND MEASURES OF MILITARY PRESENCE, 1880

\begin{tabular}{|c|c|c|c|c|}
\hline \multirow[b]{3}{*}{ Units of observation } & \multirow[b]{3}{*}{ No. of cases } & \multicolumn{3}{|c|}{ Measures of nuptiality and military presence } \\
\hline & & \multirow{2}{*}{$\begin{array}{l}\% \text { Single } 20-24 \text { with } \\
\text { soldiers } / \text { men } 20-24^{\text {a }}\end{array}$} & \multicolumn{2}{|c|}{ SMAM with } \\
\hline & & & soldiers $/$ men $20-24^{\mathrm{a}}$ & soldiers $/$ men $15-49^{b}$ \\
\hline \multirow{3}{*}{\multicolumn{5}{|c|}{$\begin{array}{l}\text { Bavarian cities } \\
\text { Prussian cities } \\
\text { Prussian adminis- } \\
\text { strative areas: }\end{array}$}} \\
\hline & & & & \\
\hline & & & & \\
\hline urban sectors & 36 & $.415^{\mathrm{d}}$ & .153 & .231 \\
\hline rural sectors $\mathrm{c}$ & 35 & .085 & -.002 & -.016 \\
\hline $\begin{array}{l}\text { urbant-rural } \\
\text { differences }\end{array}$ & 35 & $.422^{\mathrm{d}}$ & .169 & .162 \\
\hline
\end{tabular}

${ }^{\text {a}}$ For Bavarian cities, soldiers 20-24 are related to men 20-24 (instead of soldiers of all ages to men 20-24).

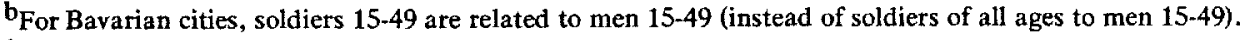
${ }^{c_{E x}}$ Excluding Berlin which has no rural sector.

d Significant at .01 level.

eSignificant at .001 level.

TABLE 11. PERCENT SINGLE AND AGE DISTRIBUTIONS AMONG FEMALE DOMESTIC SER. VANTS AND PERCENT OF WOMEN IN DOMESTIC SERVICE, PRUSSIA, 1882

\begin{tabular}{|c|c|c|c|c|c|}
\hline & \multicolumn{2}{|c|}{ Percent single } & \multirow[b]{2}{*}{$\begin{array}{l}\% \text { Of all domestics } \\
\text { in each age group }\end{array}$} & \multirow[b]{2}{*}{$\begin{array}{c}\% \text { Of age group } \\
\text { in domestic service }\end{array}$} & \multirow[b]{2}{*}{$\begin{array}{c}\text { Domestics as \% } \\
\text { of employed women }\end{array}$} \\
\hline & $\begin{array}{l}\text { Domestic } \\
\text { servants }\end{array}$ & $\begin{array}{c}\text { Total } \\
\text { women }\end{array}$ & & & \\
\hline $\begin{array}{l}10-14^{a} \\
15-19 \\
20-29 \\
30-39 \\
40-49 \\
50+\end{array}$ & $\begin{array}{r}100 \\
99.9 \\
98.7 \\
89.2 \\
75.2 \\
51.2\end{array}$ & $\begin{array}{r}100 \\
98.6 \\
56.7 \\
15.3 \\
10.3 \\
8.4\end{array}$ & $\begin{array}{r}5.0 \\
39.5 \\
42.2 \\
6.6 \\
3.1 \\
3.6\end{array}$ & $\begin{array}{c}3.9^{b} \\
33.0 \\
21.1 \\
4.1 \\
2.4 \\
1.9\end{array}$ & $\begin{array}{r}43.4 \\
46.3 \\
44.2 \\
21.8 \\
11.7 \\
8.8\end{array}$ \\
\hline Total & 96.2 & 58.2 & 100.0 & $10.4^{c}$ & 34.5 \\
\hline
\end{tabular}

Notes: Domestic servants includes Dienstboten and Gesinde as listed in the occupational census.

${ }^{2}$ All domestics listed as under 15 in the occupational census were assumed to be within the age group 10-14.

bSince the 1882 occupational census did not break down the under 15 age group into five-year age groups, the number of women 10-14 was estimated from the 1880 and 1885 population censuses by linear interpolation.

${ }^{{ }^{c}}$ Expressed as percent of women 10 and over with the number of women 10-14 being estimated as indicated in preceding note.

${ }^{\mathrm{d}}$ Employed women are defined as those listed as Hauptsberufstätig in the occupational census plus Dienstboten; this is a modification of the official definition which treats the latter category as separate from the gainfully employed.

effects of this type of employment are particularly significant because servants tended to be young women who were nearly all unmarried. Data from the $\mathbf{1 8 8 2}$ occupational census for Prussia presented in Table 11 indicate that over 85 percent of all female servants were below age 30 and 96 percent were single. Judging from the high percentage of young women in service at the time of the occupational census (a third of women 15-19 and a fifth of those 20-29), quite possibly a majority of women passed some period of their lives in domestic employment.

Domestic service, of course, was neither a uniquely urban nor female phenomenon. In 1880 , the majority of German domestics of both sexes were living in the countryside, and in fact, male domestics were almost all rural dwellers. Women domestics were somewhat more evenly split between rural and urban residences. Undoubtedly going into service in the city was a somewhat different experience for a 
woman than taking up domestic service in the countryside or in small towns. For example, urban domestics were evidently older than their rural counterparts and domestics in household service were in general older than those in agriculture. ${ }^{20}$ Furthermore, female domestics were nearly always a greater proportion of the urban population than they were of the rural population and their importance as a social group, judging from Prussia, apparently increased with city size. ${ }^{21}$

${ }^{20}$ While urban and rural female domestics were both drawn from the same population, namely single rural women in their adolescence and their twenties, there were important differences between servants in the two residence categories. Data from Berlin shows that the domestic servants in that city were older than their counterparts in the total population of Prussia. In addition, Prussian household servants (Dienstboten) were older on the average than agricultural domestic servants (Gesinde). The percent age distributions in 1882 were:

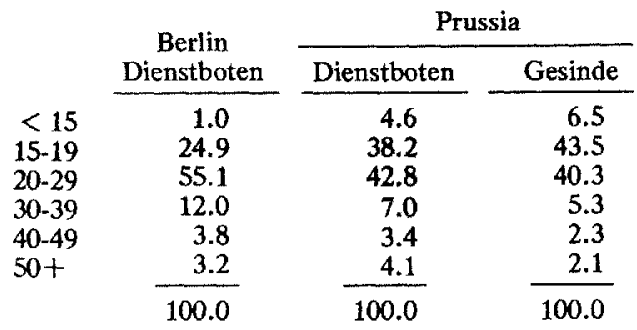

Presumably, if it were possible to separate all rural servants from all urban servants, the difference would be even more exaggerated. This suggests that urban domestic work was begun later and continued into older ages and thus may have been more important in delaying marriage in the cities than in the countryside.

${ }^{21}$ The terminology used in the German (and Prussian) population and occupational censuses is somewhat confusing. From the 1880 Prussian population census, which serves as our source of information on the number of servants in rural and urban areas as well as in the individual Prussian cities, the number of domestic servants are given under the heading "Dienstboten des Hauhaltungs-Vorstandes" in a table on the composition of family households. The occupational census, which does not provide separate data for rural and urban areas, lists two categories which can be considered as domestic servants: (1) "Gesinde und sonstige Gehülfen" who were live-in workers in the agricultural sector and (2) "Dienstboten zur Bedienung" who were household servants considered as a separate category outside the normal gainfully employed population. Kollmann (1890) discusses the problem of deriving data for domestic servants from the occupational census and suggests these two categories be added together to arrive at the total number of domestic servants. A comparison of the figures derived from the 1880 Prussian population census and 1882 occupation census on the number of domestic servants by sex are instructive:

\begin{tabular}{|c|c|c|c|}
\hline 1880 "Dienstboten" & & Males & Females \\
\hline $\begin{array}{l}\text { rural } \\
\text { urban }\end{array}$ & & $\begin{array}{r}503,454 \\
68,119\end{array}$ & $\begin{array}{l}665,597 \\
440,433\end{array}$ \\
\hline & Total & 571,573 & $1,106,030$ \\
\hline $\begin{array}{l}1882 \text { "Gesinde" } \\
\text { "Dienstboten" }\end{array}$ & & $\begin{array}{r}578,424 \\
30,752\end{array}$ & $\begin{array}{l}271,008 \\
855,425\end{array}$ \\
\hline & Total & 609,176 & $1,126,433$ \\
\hline
\end{tabular}

The sum of the two categories used in the 1882 Prussian occupational census agree roughly with the total number of domestic servants given in the 1880 population census, especially when some allowance is made for population growth. The 1880 figures indicate that male domestic servants, unlike their female counterparts, were limited largely to rural areas. The 1882 figures suggest that almost all male domestic servants were classified as agricultural "Gesinde" while only a minority of females were. Kollmann (1890:573) reports, based on the 1882 occupational census, that for Germany as a whole the category of domestic servants in household service included 1,324,924 persons of whom 97 percent were women. In order to arrive at the total number of servants he suggests adding 1,589,088 predominately male live-in agricultural employees. Using the data on domestic servants in household service alone (which are virtually all women) he reports that they represented the following percents of the total population according to urban-rural residence and city size:

$\begin{array}{ll}\text { cities } 100,000+ & 5.6 \% \\ 20,000-99,999 & 4.5 \% \\ 5,000-19,999 & 3.7 \% \\ 2,000-4,999 & 2.9 \% \\ \text { rural } & 2.2 \%\end{array}$

In addition to excluding the agricultural servants, Kollmann's figures also fail to adjust for the differences in urban and rural age and sex structures. Our results, which are for Prussia only and relate the proportion of female domestics to the women aged 15-19, are less dramatic but lie in the same direction:

$\begin{array}{ll}\text { cities } 100,000+ & 20.9 \% \\ 50,000-99,999 & 17.1 \% \\ 20,000-49,999 & 16.7 \% \\ \text { rural areas } & 15.1 \%\end{array}$


150 络需

Therefore it seems likely that urban domestic service must have had a unique impact on nuptiality.

Many of the urban domestics were migrants from the surrounding countryside. For example, in Berlin in 1885, 30 percent of all employed women were servants; of these, two-thirds had moved to the city within the previous five years and fewer than 10 percent were native Berliners (Brückner, 1890:646). In Leipzig in 1875 , only 6.8 percent of female domes. tics were native born and in Frankfurt in 1890 fewer than 3 percent were (Kuczynski, 1897:46-47). The 1860 census of Frankfurt indicates that the situation was similar 30 years earlier.

Furthermore, in some cities female servants formed a substantial proportion of all female migrants. For example, servants comprised 66 percent of all female migrants to the city of Breslau in the period from $1878-1885$ and 85 percent of female migrants to Berlin from 1876 to 1880. Domestic service seems often to have been a temporary occupation; a substantial proportion of the female migrants leaving cities were also servants (Kuczynski 1897:45-46; Bleicher, 1893, vol. 2:32). In part because of this constant replacement, domestic employment was an attraction of considerable significance, which continually drew females to cities, and swelled the numbers of single young women there. In fact, the mere availability of rural women in search of employment helped to make urban service the important institution that it was at this time. In a situation where very few forms of support were available for unmarried women, the concentration of wealthy and middle-class people in growing urban centers created a market for household help; domestic service became a convenient economic and demographic "holding category" for single young women.

Because domestic employment usually entailed celibacy, the relatively high proportions of domestics in cities would tend to raise the proportion of single women in the urban population. While it is hard to ascertain whether women were delaying marriage because of work as servants or whether they became servants because marital chances in the countryside were slim and then remained servants once in the cities because opportunities for marriage were also limited there, the association between domestic servitude in the city and celibacy is nonetheless clear.

Using data from the 1880 Prussian census on live-in domestic servants, we calculated an index of the proportion of women in service by relating the total number of female servants to the number of all women aged 15-29. ${ }^{22}$ This measure could be calculated for individual Prussian cities with a population of 20,000 or more as well as for rural and urban populations of administrative areas. Correlations between this measure and our measures of nuptiality are shown in Table 12 . Since both the presence of servants and the nuptiality measures show distinct regional differences the results are presented both unadjusted and adjusted for this factor. ${ }^{23}$ Within the Prussian cities, there are high, positive correlations between the proportion of female servants in the population and both female singulate mean age at marriage and measures of celibacy. Particularly noteworthy is the finding that domestic service is strongly related not only to the proportion single in the younger ages but also to celibacy at ages 45-49. The extreme cases are of interest.

${ }^{22}$ All servants of course are not in the ages $15-29$ although as Table 11 indicates over 80 percent were. Alternative indices relating servants to women 20-29 and women 15-49 were also tried. Correlations between these indices, however, were so high (usually over .99) that results were essentially identical.

${ }^{23}$ The ratio of servants to women aged 15-29 was higher in the eastern cities and urban sectors of the eastern administrative areas than elsewhere in Prussia. 
TABLE 12. CORRELATION COEFFICIENTS BETWEEN THE RATIO OF FEMALE DOMESTIC SERVANTS TO WOMEN AGE 15-29 AND MEASURES OF NUPTIALITY, PRUSSIA, 1880

\begin{tabular}{|c|c|c|c|c|}
\hline & Cities $20,000+$ & Urban areas & Rural areas ${ }^{2}$ & $\begin{array}{l}\text { Urban-rural } \\
\text { differences }^{\mathrm{a}}\end{array}$ \\
\hline \multicolumn{5}{|l|}{ Unadjusted for regional location } \\
\hline $\begin{array}{l}\text { Servants/women } 15-29 \text { with } \\
\% \text { single } 20-24 \\
\% \text { single } 25-29 \\
\% \text { single } 45-49 \\
\text { SMAM } \\
\text { Number of cases }\end{array}$ & $\begin{array}{l}.705^{\mathrm{d}} \\
.732^{\mathrm{d}} \\
.699^{\mathrm{d}} \\
.591^{\mathrm{d}} \\
69\end{array}$ & $\begin{array}{l}.438^{c} \\
.456^{c} \\
.251 \\
.457^{c} \\
36\end{array}$ & $\begin{array}{r}.136 \\
.208 \\
-.273 \\
.285 \\
35\end{array}$ & $\begin{array}{l}.510^{\mathrm{d}} \\
.593^{\mathrm{d}} \\
.551^{\mathrm{d}} \\
.469^{\mathrm{c}} \\
35\end{array}$ \\
\hline \multicolumn{5}{|l|}{ Adjusted for regional location ${ }^{b}$} \\
\hline $\begin{array}{l}\text { Servants/women } 15-29 \text { with } \\
\% \text { single } 20-24 \\
\% \text { single } 25-29 \\
\% \text { single } 45-49 \\
\text { SMAM } \\
\text { Number of cases }\end{array}$ & $\begin{array}{l}.693^{\mathrm{d}} \\
.714^{\mathrm{d}} \\
.741^{\mathrm{d}} \\
.555^{\mathrm{d}} \\
69\end{array}$ & $\begin{array}{l}.507^{\mathfrak{c}} \\
.511^{\mathrm{c}} \\
.426^{\mathrm{c}} \\
.429^{\mathrm{c}} \\
35\end{array}$ & $\begin{array}{c}.300 \\
.413^{\mathfrak{c}} \\
-.009 \\
.375 \\
34\end{array}$ & $\begin{array}{l}.593^{d} \\
.711^{d} \\
.458^{d} \\
.619^{d} \\
34\end{array}$ \\
\hline
\end{tabular}

In Frankfurt/Main where the proportion of servants was highest, the singulate mean age of marriage of women was a year above the average of the Prussian cities while in Linden in Hannover, where female servants were least common, the singulate mean age of marriage was nearly 2 years below the average for the Prussian cities. The proportion single at ages 45-49 in Linden was less than 5 percent and close to the lowest level for any Prussian city while in Frankfurt 21 percent of women at these ages were still single which is almost twice the average for all cities.

A somewhat similar situation holds for the urban sectors of the Prussian administrative areas: the higher the proportion of female servants, the greater the tendency for women to remain single while in their twenties and to marry late. In rural areas, however, while this relationship is still positive with all measures of nuptiality except the percent single $45-49$, it is very weak. This is consistent with the view that rural domestic service is a somewhat different phenomenon than urban domestic service and thus did not have the same effect on marriage patterns. Finally, the importance of servants in accounting for urban-rural differences in nuptiality within the Prussian administrative areas is also clear from Table 12. Where there were large differences in the proportion of servants in the rural and urban sectors of an administrative area, there were also likely to be relatively large urban-rural differences in nuptiality measures.

Adjusting for regional locations has little effect on the results for the Prussian cities but generally strengthens the associations of servants with higher proportions single and later marriage in the rural and urban sectors of the administrative areas and especially strengthens the relationships between urban-rural differences in domestic service and nuptiality. Thus both for Prussia as a whole and within regions, there is a substantial association between domestic service and marriage patterns.

Imbalances in the sex ratio of the adult population that result when streams of migrants are sex-selective are commonly 


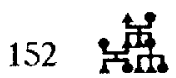

cited as consequences of migration which affect marriage probabilities (e.g., Wrigley 1961:140). Military service and urban domestic employment are simply two extreme examples of activities which selected migrants of one sex. Mining and work in textile factories are two other examples often cited. Indeed, a whole range of economic activities which drew people to the cities or from the one region to another favored one sex over the other. Since activities which attracted men were not necessarily located in the same places and did not necessarily draw from the same geographic pool of migrants as those which attracted women, severe local imbalances between the numbers of men and women of marriageable age could arise. In our analysis of the impact of the sex structure on nuptiality, we will be focusing on the ratio of men aged 25-39 to women aged $20-34 .^{24}$ The sex ratio, so defined, varied widely for different areas in Germany and particularly in cities. For example, in the largely administrative and commercial cities of Bonn and Wiesbaden in the West and Tilsit and Bromberg in the East, there were only 60 or 70 men aged 25-39 for every 100 women aged 20-34 according to the 1880 census. Female domestics were common in all these cities; indeed, in Bonn and Wiesbaden women servants were more prevalent than in almost all of the other large Prussian cities. In sharp contrast to this, men aged 25-39 actually outnumbered women five years younger in the Prussian industrial cities of Bochum, Spandau, Remscheid, Dortmund, Essen, and Duisburg. Equally

${ }^{24}$ In nineteenth-century Germany, most single women who married did so between the ages of 20 and 34; for men, marriage before age 25 was uncommon and most men who married did so before age 40 . The main advantage of our measure is to focus on the balance between the sexes during the prime marriageable ages. In addition, by eliminating men under 25 , the measure avoids most of the confounding influence the military population would have on sex ratios in garrison towns. large differences in the ratio of men to women in these ages characterized Bavarian cities: in Bamberg, Landau, and Speyer the sex ratio was only 71 while in Amberg it was 125. There were also wide differences in the balance between the sexes in rural areas. Among the 61 German administrative areas for which we have data on the rural sector, the sex-ratio ranged from 73 in Upper Silesia (Oppeln) in the East to 105 in Arnsberg in the West. Indeed, sex ratios were generally low in both rural and urban sectors in the East because the exodus to other more prosperous areas of Germany was predominately male. The destinations of many of these eastern male migrants were in western areas of Prussia such as Arnsberg, where employment opportunities in coal mining and heavy industry were rapidly developing.

Table 13 indicates the degree of correlation between the sex ratio and both the percent single at ages 45-49 and the singulate mean age at marriage. Since there was a distinct regional pattern to sex ratios as well as most of the nuptiality measures, results are also shown adjusted for regional location. ${ }^{25}$

All else being equal, the sex ratio should show opposite relationships with male and female nuptiality. High sex ratios, which indicate a greater availability of men and a shortage of women in the marriageable ages, should be associated with high male

\footnotetext{
${ }^{25}$ Sex ratios are distinctly lower in the eastern region than in all other regions in cities as well as in urban and rural sectors of administrative areas. Average differences among the other three regions are less pronounced although the highest sex ratios (i.e., the great preponderance of males) for Prussian cities and for rural sectors of the administrative areas are found in the West. For urban sectors, the average sex ratio is slightly higher in the central region than in the West. The regional differences in sex ratios are partly explained by the stream of migrants from the eastern areas of Prussia to the central and especially western areas. As noted before, long range migrants tended to be predominantly male (c.f. Köllmann, 1974:173).
} 
TABLE 13. CORRELATION COEFFICIENTS BETWEEN THE RATIO OF MEN 25-39 TO WOMEN 2034 AND MEASURES OF NUPTIALITY, 1880

\begin{tabular}{|c|c|c|c|c|c|c|}
\hline & \multicolumn{3}{|c|}{$\begin{array}{l}\text { Unadjusted for } \\
\text { regional location }\end{array}$} & \multicolumn{3}{|c|}{$\begin{array}{l}\text { Adjusted for } \\
\text { regional location }\end{array}$} \\
\hline & Men & Women & $\begin{array}{c}\text { Men- } \\
\text { women }\end{array}$ & Men & Women & $\begin{array}{c}\text { Men- } \\
\text { women }\end{array}$ \\
\hline $\begin{array}{l}\text { Prussian cities }(\mathrm{N}=69) \\
\% \text { single } 45-49 \\
\text { SMAM }\end{array}$ & $\begin{array}{r}-.254 \\
-. .147\end{array}$ & $\begin{array}{l}-.606^{f} \\
-.776^{f}\end{array}$ & $.641^{\mathrm{f}}$ & $\begin{array}{l}-.331^{b} \\
-.097\end{array}$ & $\begin{array}{l}-.660^{\mathrm{f}} \\
-.755^{\mathrm{e}}\end{array}$ & $\begin{array}{l}.664^{f} \\
.739^{f}\end{array}$ \\
\hline $\begin{array}{l}\text { Bavarian cities }(\mathrm{N}=49)^{\mathrm{c}} \\
\text { \% single 45-49 } \\
\text { SMAM }\end{array}$ & $\begin{array}{r}-.088 \\
.086\end{array}$ & $-.185 \mathrm{f}$ & $\begin{array}{l}.363^{\mathrm{e}} \\
.538^{\mathrm{f}}\end{array}$ & - & - & - \\
\hline $\begin{array}{l}\text { Administrative Areas: } \\
\text { Urban Sectors }(\mathrm{N}=62)\end{array}$ & & & & & & \\
\hline $\begin{array}{l}\text { \% single } 45-49 \\
\text { SMAM }\end{array}$ & $\begin{array}{l}.159 \\
.094\end{array}$ & $\begin{array}{l}-.218 \\
-.601^{f}\end{array}$ & $\begin{array}{l}.450^{\mathrm{e}} \\
.670^{\mathrm{e}}\end{array}$ & $\begin{array}{l}.147 \\
.212\end{array}$ & $\begin{array}{l}-.354^{\mathrm{e}} \\
-.485^{\mathrm{f}}\end{array}$ &. $.572^{f} f$ \\
\hline $\begin{array}{l}\text { Rural Sectors }(N=61)^{d} \\
\% \text { single } 45-49 \\
\text { SMAM }\end{array}$ & $\begin{array}{l}.571^{\mathrm{f}} \\
.595^{\mathrm{f}}\end{array}$ & $\begin{array}{l}.233 \\
.083\end{array}$ & $\begin{array}{l}.442^{\mathrm{f}} \\
.669^{\mathrm{f}}\end{array}$ & $\begin{array}{l}.380^{\mathrm{e}} \\
.385^{\mathrm{e}}\end{array}$ & $\begin{array}{l}-.194 \\
-.025\end{array}$ & $.635^{f}$ \\
\hline $\begin{array}{l}\text { Urban-rural } \\
\text { differences } \\
\% \text { single } 45-49 \\
\text { SMAM }\end{array}$ & $\begin{array}{l}.352^{\mathrm{e}} \\
.262\end{array}$ & $\begin{array}{l}-.489^{\mathrm{f}} \\
-.241\end{array}$ & $.667^{\mathrm{f}}$ & $\begin{array}{l}.227 \\
.258\end{array}$ & $\begin{array}{l}-.432^{\mathrm{f}} \\
-.325^{\mathrm{e}}\end{array}$ & $\begin{array}{l}.597^{\mathrm{f}} \\
.604^{\mathrm{f}}\end{array}$ \\
\hline
\end{tabular}

${ }^{\mathrm{a}}$ Correlations of deviations from regional means.

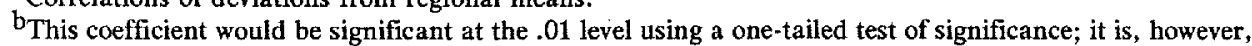
in the opposite direction as predicted.

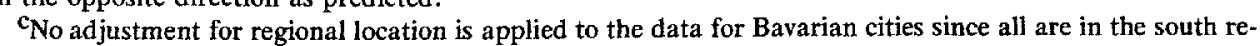
gion.

${ }^{\mathrm{d}}$ Excluding Berlin which has no rural sector.

esignificant at the .01 level.

fSignificant at the .001 level.

but low female celibacy and late male but early female marriage; low sex ratio, i.e., a preponderance of women, should be associated with the opposite. The expected negative association between the sex ratio and female nuptiality is most apparent for Prussian cities, more moderate for the urban sectors of administrative areas, and present although even weaker for the Bavarian cities. In rural sectors of administrative areas, the relationship is negligible and even in the opposite direction before adjusting for regional location. The opposite is true for association between the sex ratio and male nuptiality; it is negligible and often negative in Prussian and Bavarian cities as well as in the urban sectors of administrative areas but strongly positive in the rural sectors. Correlations between sex ratios and urban-rural differences in nuptiality are, however, in the expected direction for both men and women although not always statistically significant. The most consistent and usually strongest association (especially after statistically controlling for regional location) is between the sex ratio and malefemale differences in celibacy and age at marriage.

This rather complicated set of results deserves some comment. We can speculate on several interpretations. Of course, sex ratios are only one factor affecting marriage patterns and are, so to speak, superimposed on cultural and socio-economic factors, indeed in part determined by the latter. It is impossible to control for all these other relevant factors although by adjusting for regional location presumably at least some statistical control is introduced. To the extent that these other factors affect both male and female marriage patterns, in the same way they must weaken the overall relationship 


\section{4 苦藏}

between the sex ratio and nuptiality for either males or females or both since the sex ratio is expected to operate on male and female nuptiality in opposite directions. For example, if customs or inheritance patterns or poor economic conditions encourage late marriage or high levels of celibacy in an area for both men and women, while in another area local conditions encourage early and universal marriage, the difference in observed nuptiality patterns between these two areas could be consistent with patterns predicted from sex-ratio differences for either males or females but certainly not for both. In fact, male and female nuptiality measures are highly correlated in each of the data sets: Prussian and Bavarian cities, rural and urban sectors of administrative areas, and entire administrative areas. ${ }^{26}$ This suggests that sex ratios are not likely to explain much of the nuptiality differences between areas. Nonetheless such factors could influence male-female differences within an area in the nuptiality measures in a manner consistent with effects of the sex ratios. For example, both in areas where celibacy is generally high and in areas where celibacy is generally low, the differences between male and female celibacy could respond to sex ratios. Under such circumstances, it seems reasonable that the sex ratio is most strongly related with the male-female differences in nuptiality rather than with either male or female nuptiality separately since it is the marriage probability of one sex relative to the other that is most directly influenced by sex ratios.

Sex ratios indicate that in general in late

${ }^{26}$ The correlation between the male and female proportion single at ages $45-49$ ranged from .57 for Prussian cities to .79 for all German administrative areas; for the male and female singulate mean ages at marriage the correlations are weaker ranging from .44 for urban sectors of administrative areas to .67 for rural sectors. nineteenth-century Germany the supply of men in marriageable ages relative to women was greater in the countryside than in urban areas. This may help to explain why celibacy in cities was consistently higher for women than for men, and virtually always higher for women in urban areas than for their rural counterparts. Of course, urban sex ratios were not always lower than rural ones and it is noteworthy that in the unusual case of the city-state of Hamburg, the sole administrative area where female celibacy was higher in the countryside, the urban sex ratio exceeded the rural one to a greater extent than anywhere else.

Urban sex ratios were also of great importance in determining the age at which women married, in addition to their possibility of ever marrying. Within Prussian cities and urban areas, women married youngest where there was a relative surplus of men (i.e., where sex ratios were high). On the other hand, men do not seem to have married later or less under the same circumstances. These results may seem surprising, but they conform with patterns observed in the western Prussian cities for the late nineteenth century by E. A. Wrigley (1961:145-146), who found female nuptiality patterns to be much more variable than male patterns were. That is, men presumably made their decisions about when to marry based upon such factors as their ability to support a family. Those who had migrated to the cities which were attracting a lot of young men did so because there were jobs there. When they were ready to marry, they could marry either local women or women from back home. ${ }^{27}$ Thus men in cities

${ }^{27}$ Kollimann (1974:177) infers from indirect evidence that a substantial proportion of women coming from northeastern Germany to the large cities of the Rhur did so specifically to marry a partner who had migrated earlier and had managed in the meantime to establish himself sufficiently to afford marriage to his future bride who had been waiting back home. 
were not as constrained by sex ratios as were women in cities or, for that matter, as men living in rural areas were. Indeed, the fact that rural men were probably more limited to finding marrige partners from the local supply of women may help explain why nuptiality patterns of rural men seem to be more affected by sex ratios. Likewise, where there were large surpluses of women in cities, female marital chances were poor. Wrigley (1961:145) found this to be the case in textile towns. A woman either had to choose a mate from among the relatively small number of men living in the city, or if she were a migrant, go back to her home to marry. Presumably she did not have the same ability to send for someone waiting back at home as male migrants did.

There is possibly a similar explanation for the weakness of the negative correlation in rural areas (adjusted for region) between sex ratios and female age at marriage. Where rural sex ratios were low this was because of excessive out-migration of men who undoubtedly were disproportionately single compared to men who remained behind. Those men who did not migrate were not only more likely than outmigrants to be married but may well have married when both they and their brides were young, thus accounting for the lack of an unusually high age of marriage for women who marry in such areas. Nonetheless, one would still expect an association between low rural sex ratios and high female celibacy. The lack of a stronger negative correlation between sex ratios and the proportion single among women $45-49$ in rural areas remains puzzling. The situation is undoubtedly complicated by return migration of women who worked temporarily in the cities.

Finally, comment on the relationship between urban-rural differences in marriage and urban-rural differences in sex ratios seems appropriate. The correlations are in the direction expected but are sometimes quite weak, particularly for the singulate mean age at marriage. It is worth noting that in a number of areas, urban values of the nuptiality measures for both men and women were either higher or lower than rural values in the same area. ${ }^{28}$ In these cases, the urban-rural differences in the sex ratios obviously can not account for the direction of the urban-rural differences in marriage for both men and women since it should affect the two sexes in opposite ways. For example, in the eastern areas of Posen, Bromberg, and Marienwerder, the singulate mean age at marriage of both men and women was significantly higher in urban than rural sectors, close to the extreme for both sexes. Both rural and urban sex ratios were relatively low and urban-rural differences in sex ratios were small or moderate. On the other hand, in the western areas of Aachen, Münster, and Osnabruck, both men and women were marrying quite a bit earlier in the cities than in rural areas. Sex ratios were unusually high in rural sectors of these areas, particularly in Aachen, and about average in the cities. These cases demonstrate the fact that the influence of sex ratios on urban-rural differences in nuptiality is complex; predictions about its impact in particular cases must be informed by additional information concerning the nature and source of local sex imbalances and the general character of nuptiality in the area. ${ }^{29}$ In summary,

${ }^{2 B}$ It should be noted that sex imbalances between the urban and rural sectors of an administrative area were not necessarily complementary. Migration from outside the area was often the cause of urban imbalance. In fact, the correlation between sex ratios in urban and rural sectors of the administrative areas is actually positive, and significant $(.50)$.

${ }^{29}$ One of the factors influencing urban sex ratios of course is the prevalence of domestic servants, who were almost entirely female in urban areas. The ratio of female servants to women 15-29 correlates nega- 
sex-ratio imbalances had different effects on nuptiality in urban and rural areas, and a different impact on the marital chances of men and women. The impact of sex ratio imbalance was felt most strongly by those groups whose choice of a spouse was most circumscribed; namely, women in predominantly female cities and men in those rural areas where women were relatively scarce. Furthermore, there is evidence that within areas, sex-ratios had substantial influence upon differences between male and female ages at marriage and celibacy.

\section{Conclusions}

Historians who have been interested in nuptiality as part of the social behavior of the past have often focused on the link between economic independence and marriage. They have correctly pointed to occupational differentials in age at marriage and celibacy in this context. Indeed a number of occupations associated with the transformation of Europe from a rural agricultural society to an urban industrial one were characterized by relatively early entry into marriage and lower proportions remaining single than were characteristic of agricultural occupa-

tively with the sex ratio both for Prussian cities (-.54) and for the urban sectors of Prussian administrative areas $(-.37)$. Together the sex ratio and domestic servants account for considerable variation in urban levels and urban-rural differences in female nuptiality as indicated by the following multiple correlations (both adjusted and unadjusted for regional location):

\begin{tabular}{|c|c|c|c|c|}
\hline & \multicolumn{2}{|c|}{$\begin{array}{l}\mathbf{R}^{2} \text { unadjusted for } \\
\text { regional location }\end{array}$} & \multicolumn{2}{|c|}{$\begin{array}{l}\mathbf{R}^{2} \text { adjusted for } \\
\text { regional location }\end{array}$} \\
\hline & $\begin{array}{c}\% \\
\text { single } \\
45-49\end{array}$ & SMAM & $\begin{array}{c}\% \\
\text { single } \\
45-49 \\
\end{array}$ & SMAM \\
\hline $\begin{array}{l}\text { Prussian cities } \\
\text { Prussian } \\
\text { administrative }\end{array}$ & .56 & .64 & .66 & .61 \\
\hline $\begin{array}{l}\text { Urban sectors } \\
\text { Urban-rural }\end{array}$ & .15 & .54 & .38 & .41 \\
\hline differences & .38 & .22 & .23 & .40 \\
\hline
\end{tabular}

tions, especially peasant farming. ${ }^{30} \mathrm{Min}$ ing and factory work perhaps epitomize occupations in which early economic independence and early marriage with low celibacy were associated (Haines, 1975; Kollman, 1890; Prinzing, 1903; Von Fircks, 1889). Indeed for most couples in nineteenth-century Germany, there was undoubtedly an intimate link between the decision to marry and the attainment of a sufficient livelihood. Just as clear was the tendency for men in different types of work to reach maximum earning power at different ages (Kollman, 1890:598-607). The differences in types of work and methods of attaining economic sufficiency between the urban and rural sectors of some areas were undoubtedly related to differences in marriage patterns. Yet, though a number of industrial occupations characterized by early attainment of economic sufficiency were urban in nature, our study of urban-rural differentials in nuptiality indicates it would be incorrect to conclude from this that urban life in general was characterized by early marriage and low celibacy. Indeed, our findings suggest the opposite: the age at marriage and percent never marrying were higher in the cities than in the countryside. ${ }^{31}$ The reasons are quite complex and

${ }^{30}$ It is worth noting that despite the rapid pace of both urbanization and industrialization in Germany during the latter part of the nineteenth century, the national statistics indicate that age at marriage and the proportion remaining permanently single changed little between 1880 and 1910 suggesting that the overall relationship between industrialization and marriage was at best very weak (Knodel, 1974:70).

\footnotetext{
${ }^{31}$ Although our measures are somewhat biased as discussed in the appendix, the biases do not appear to be large enough to account for our general findings. In addition, estimates of the age specific probabilities of marrying for 1880 derived from relating the number of martiages (including remarriages) to the number of non-married for Prussia confirm that chances of marrying were typically lower in the cities:
} 
we have only explored a few aspects of the total picture.

Perhaps the main set of factors accounting for urban-rural marriage differentials emerge from the intricate links between marriage, migration, and economic opportunity. Our discussion of rural and urban differences in military presence and domestic service deals with only a part of this problem. The impact of garrisons in towns and cities is the least problematic since military migration tended to be temporary and was concentrated in ages when few men were marrying anyway. Domestic service, as we have shown, is of much greater significance in explaining the late marriage and high celibacy of the nineteenth-century German city. The large number of female domestics in the cities were recruited almost exclusively from the countryside where prospects for marriage were probably remote for many of them. There were undoubtedly only limited possibilities in the rural areas for their potential partners to earn a livelihood sufficient for establishing a family. But though their move to the city may have relieved the economic pressure on their parents and might have been seen as good preparation for eventually being in charge of a household of their own, it did not necessarily enhance their chances of finding a spouse. Instead it increased the number of single women in the cities and put them in an occupational situation in which exposure to eligible spouses was quite restricted. Women in other types of urban employment did not necessarily fare much better; their ranks were swollen by continual migration and they had to

\begin{tabular}{|c|c|c|c|c|}
\hline & \multicolumn{4}{|c|}{ Age specific marriage rates, 1880} \\
\hline & \multicolumn{2}{|c|}{ men } & \multicolumn{2}{|c|}{ women } \\
\hline & $20-29$ & $30-39$ & $20-29$ & $30-39$ \\
\hline $\begin{array}{l}\text { Rural } \\
\text { Total urban } \\
\text { Cities } 20,000+\end{array}$ & $\begin{array}{l}.104 \\
.075 \\
.066\end{array}$ & $\begin{array}{l}.142 \\
.133 \\
.125\end{array}$ & $\begin{array}{l}.124 \\
.106 \\
.092\end{array}$ & $\begin{array}{l}.091 \\
.077 \\
.070\end{array}$ \\
\hline
\end{tabular}

compete for men who could choose wives among both city women and women back home. And although both men and women came to work in the cities, the jobs in which they worked were typically different and sex-segregated; on-the-job contact between the sexes was unusual for many.

On the aggregate level with which we are dealing, men in cities differed less from their rural counterparts with respect to marriage patterns than did women. We have already suggested a possible explanation for this: men in cities were probably better off economically and were not as constrained by sex ratios as women were. Yet the evidence suggests that although the differences were small, men also married later, not earlier, in the cities, and were more likely to remain permanently single there than in the countryside. Part of the explanation lies in the fact that large proportions of both male and female populations of nineteenth-century cities in Germany were not urban natives but migrants from rural areas. There is some direct evidence for Frankfurt and Berlin indicating that migrants in these cities married later than natives; there was also a difference between natives and migrants with respect to the extent of permanent celibacy; with the exception of female migrants to Frankfurt, celibacy was lower among migrants. ${ }^{32}$ It should be noted as well that in both of these cases city natives, while marrying earlier than migrants, were still marrying as late or later than residents of the surrounding countryside. Celibacy

${ }^{32}$ The following figures are based on the 1885 Berlin Census and the 1891 Frankfurt Census:

\begin{tabular}{|c|c|c|c|c|}
\hline & \multicolumn{2}{|c|}{ Men } & \multicolumn{2}{|c|}{ Women } \\
\hline & Native & Migrant & Native & Migrant \\
\hline Berlin & & & & \\
\hline $\begin{array}{l}\text { SMAM } \\
\% \text { single }\end{array}$ & 28.22 & 28.57 & 25.49 & 26.59 \\
\hline $\begin{array}{r}45-49 \\
\end{array}$ & 9.7 & 8.2 & 15.0 & 10.1 \\
\hline Frankfurt & & & & \\
\hline $\begin{array}{l}\text { SMAM } \\
\% \text { single }\end{array}$ & 28.56 & 28.92 & 25.76 & 27.36 \\
\hline $40-49$ & 16 & 12 & 17 & 17 \\
\hline
\end{tabular}


158

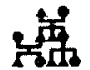

among urban natives was also substantially higher than in nearby rural areas. Migration was undoubtedly selective of those who were single and of those whose economic prospects at home were probably severely limited. Had they remained at home, perhaps even a higher proportion of the migrants might have remained celibate and those who would have married might have waited longer to do so. This of course we do not know. Under such circumstances however, it seems understandable that urban areas were not characterized by young and universal marriage. Perhaps the urban forms of employment could permit some people to marry earlier. But this effect seems to have been offset by the fact that the labor force in many cities was recruited from rural migrants; migration was often associated with delayed marriage. Despite the fact that migration affects our measurements of nuptiality, it is clearly also apart from this a critical factor in understanding rural and urban patterns of marriage.

The results of our investigation of nineteenth-century German nuptiality raise many questions we have not been able to answer and suggest a number of further directions for exploration. Certainly the whole question of migration and its impact on nuptiality deserves further attention. The relationship between occupation and marital possibilities is also important and work on that problem has only begun. Our study also points to the important regional character of many aspects of nuptiality; sorting out the complete set of factors that compose a regional pattern presents a real challenge.

Clearly the impact of the urban environment on the lives of city residents as well as its repercussions for rural populations are intriguing and complex historical issues. The vast collection of published statistical material gathered in the latter half of the nineteenth century and often tabulated separately for individ- ual cities and for rural and urban sectors of the population should prove an invaluable source for the task ahead. The present study, utilizing such data, hopefully contributes to the contemporary effort to understand the character of urban life during a critical period of social and economic transformation in Europe. Appendix: Notes on the Use of Proportions Single and the Singulate Mean Age at Marriage for Studying Urban and Rural Nuptiality Patterns in Nineteenth.Century Germany

Differences in mortality and migration between the single and ever-married affect the use of proportions single and the singulate mean age at marriage as measures of nuptiality. The result of mortality differentials is to reduce the proportions single at older ages and raise the mean age of marriage computed from the proportions single in comparison to a situation where mortality selectivity would be absent. However, Hajnal has estimated the extent of this effect and it appears to be quite small. The effect is apparently greater for men than for women. Even among men it seems unlikely to reduce the proportion single by ages $45-49$ by as much as 10 percent of its value or to raise the computed age of marriage by more than a few tenths of a year (Hajnal 1953: 126129). For making urban-rural comparisons, the slight bias resulting from mortality selectivity is relatively unimportant since presumably it operates in the same direction for both rural and urban populations.

Of greater concern is the effect of migration differentials by marital status. Using migration statistics from Sweden, Hajnal (1953:126-129) has shown that the differential loss by marital status through migration has only a small effect on the proportions single and singulate mean age of marriage at the national level. Agarwala (1962), who uses a measure related to Hajnal's singulate mean age at marriage 
but based on two censuses (rather than just using one census) finds that on the provincial level in India, his measure is robust with regards to the effect of migration. However the problem is more serious when dealing with urban and rural comparisons. Although both rural and urban areas may have been losing some population through net emigration abroad, cities in the late nineteenth century were typically gaining population from the rural areas, not only in Germany but throughout Europe (Weber, 1899). Thus the effect of migration selectivity operated in opposite directions for the rural and urban populations.

Assuming that the transfers from rural to urban areas were proportionately greater for the single population than for the married at most ages, the effect would be to reduce the proportion single in the sending areas and inflate the proportion single in the receiving areas. The matter is further complicated by the possibility that migration selectivity of both in-migrants and out-migrants may differ according to the direction of migration. For example, if in-migrants to the cities were disproportionately single but return migrants to the countryside were disproportionately married, the impact on urban-rural differences in proportions single would be even more pronounced.

Determining the effect of urban-rural migration on the singulate mean age of marriage is even more complicated than estimating its effect on the proportions single since it depends on many factors including the extent and age pattern of selectivity by marital status, the magnitude of migration relative to the sending and receiving populations, the age pattern of migrations, and the proportion single at various ages. In short it is difficult to estimate how much effect migration has on rural and urban proportions single and on calculations of the singulate mean age at marriage. In late nineteenth-century
Germany, where there was substantial rural to urban migration concentrated in the ages between 15 and 24 , this effect would almost certainly lower the rural age of marriage and raise the urban age of marriage as estimated in this way.

A hypothetical example gives at least a very rough idea of the magnitude of the effect. Assume the following:

1. A rural and an urban female population with identical age distributions but differing size by a factor of 2.75 (the approximate ratio of the rural population to the population of cities of 20,000 or more population in Prussia in 1880).

2. Both populations are initially characterized by the proportions single by age characterizing all Prussian women in 1880 . Hence they initially have identical singulate mean ages of marriage.

3. Net migration occurs transferring from the rural to the city population sufficient numbers to raise the number of women in the cities aged 15-24 by 30 percent, those aged $25-29$ by 10 percent, and those aged $30-49$ by 5 percent (these figures roughly approximate the increase of women in Prussian cities by net migration between 1880 and 1885 ).

4. The marital status distribution of these migrants was approximately equal to the marital status of migrants to Berlin in $\mathbf{1 8 8 5}$ and tabulated in the 1885 Berlin census (i.e., migrants enumerated in the December 1885 census who had arrived in Berlin sometime during the census year).

Under these assumptions, the impact of the migration would be to raise the urban and lower the rural singulate mean age at marriage so that there would be approximately half a year difference in the estimated age of marriage as a result of the transfer of the migrants from the rural areas to the cities. Since the volume of 
migration in this example was approximately equal to the amount that would take place over five years and no allowance is made for the fact that some of the single migrants would marry within the five-year period, this estimation of the effect of migration on rural urban differences is probably exaggerated. (Note however that the selectivity of migrants for being single might be underestimated since presumably some of the women moving to Berlin in 1885 were married between their arrival and the time of the 1885 census).

Despite this complication in the measure, the use of proportions single has one important intrinsic advantage over marriage registration data, in addition to availability, in connection with the study of urban-rural marriage patterns. The singulate mean age of marriage is independent of the age distribution of the population for which it is calculated while the conventional mean age of marriage calculated from marriage registration data is not. Since there are often substantial differences in the age distribution of the marriageable population in rural and urban areas, this is a consideration of some importance. In Prussia in 1880, for example, the proportion of the male single population aged between 15 and 49 that was in the ages $20-24$ was substantially higher in cities than in rural areas. Thus even if the probabilities of first marriage by age were identical in both areas, the proportion of marriages that occurred at these relatively young ages would be greater for the city than for the rural population and would yield a younger mean age at marriage for the city population giving the false impression that persons were more likely to marry younger in the city than in the countryside. Under similar circumstances (provided the probabilities of first marriages had been constant in the past), the singulate mean age at marriage would be identical for each population. A hypothetical example indicates the magnitude of this effect. By applying the age schedule of first marriage probabilities for the married population of the state of Oldenburg in the years 1924-26 (one of the few such schedules available for a German state for five-year age groupings) to the 1880 Prussian age distributions of the single rural men 15-49 and single men in cities $20,000+$, the average age of the resulting marriages is half a year younger in cities than the countryside even though the same marriage rates were being applied. The equivalent results for women are in the opposite direction and indicate that the average age of first marriages in the cities would be eight-tenths of a year older than in rural areas.

\section{BIBLIOGRAPHY}

Agarwala, S, N.

1962 Age at Marriage in India. Allahabad: Kitab Mahal.

Bleicher, $\mathrm{H}$.

1893 Beiträge zur Statistik der Stadt Frankfurtam-Main. Vol. I and II. Frankfurt.

Brückner, $\mathrm{N}$.

1890 "Die Entwicklung der Grosstädtischen Bevooulkerung im Gebiete des Deutschen Reichs." Allgemeines Statistisches Archiv I:135-184 and 615-672.

Dixon, Ruth

1971 "Explaining Cross-Cultural Variations in Age at Marriage and Proportions Never Marrying." Population Studies 25:215-233.

Eversley, D. E. C.

1965 "Population, Economy and Society." In D. V. Glass and D. E. C. Eversley, eds., Population in History. London: Arnold.

Gaskin, Katharine

1975 "An Analysis of Age at First Marriage in Europe Before 1850." Unpublished MS.

Habakkuk, H. J.

1965 "The Economic History of Modern Britain." In D. V. Glass and D. E. C. Eversley, eds., Population in History. London: Arnold.

Haines, Michael

1975 Fertility and Occupation: Coal Mining in the Nineteenth and Early Twentieth Centuries in Europe and America. Western Societies Program Occasional Paper No. 3, Cornell University. 


\section{JOURNAL OF FAMILY HISTORY}

Hajnal, John

1953 "Age at Marriage and Proportions Marrying." Population Studies 7:111-136.

1965 "European Marriage Patterns in Perspective." In D. V. Glass and D. E. C. Eversley, eds., Population in History. London: Arnold.

Knodel, John

1974 The Decline in Fertility in Germany, 18711937. Princeton: Princeton University Press.

\section{Kollmann, $P$}

1890 "Die Soziale Zusammensetzung der Bevoòkerung im Deutschen Reich." Allgemeines Statistisches Archiv 1:540-614.

\section{Kơllmann, Wolfgang}

1974 Bevởkerung in der Industriellen Revolution. Gö́ttingen.

Kuczynski, R.

1897 Der Zug Nach der Stadt. Stuttgart: J. G. Cotta'sche Buchhand.

Livi Bacci, Massimo

1976 Personal communication.

Nie, H., et. al.

1975 SPSS: Statistical Package for the Social Sciences. New York: McGraw-Hill.

Oldenburg Statistical Bureau

1874 Statistischen Nachrichten über das Grossherzogthum Oldenburg. Heft 14. Oldenburg.

Petersen, W

1960 "The Demographic Transition in the Netherlands." American Sociological Review 25:334-347.

Prinzing, Friedrich

1903 "Heiratshaufigkeit und Heiratsalter nach
Stand und Beruf." Zeitschrift fur Sozialwissenshaft 6:546-559.

SkJar, June L.

1974 "The Role of Marriage Behaviour in the Demographic Transition: The Case of Eastern Europe Around 1900." Population Studies 28:231-247.

Tilly, Louise, Joan Scott, and Miriam Cohen

1976 "Women's Work and European Fertility Patterns." Journal of Interdisciplinary History $3: 447-476$.

Van de Walle, Etienne

1968 "Marriage and Marital Fertility." Daeđalus 97:486-501.

Von Fircks, A

1889 "Die Berufs-und Erwerbsthätigkeit der Eheschliessenden Personen in Ihrem Ein. flusse auf deren Verheirathbarkeit ...." Zeitschrift des Koniglich Preussischen Statistischen Bureaus 29:165-203.

Wappaus, J. E.

1961 Allgemeine Bevolkerungsstatistik. Leipzig: J. C. Hinrichs.

Weber, Adna

1899 The Growth of Cities in the Nineteenth Century. New York: Macmillan Company.

Wirminghaus, $\mathrm{A}$.

1895 "Stadt und Land unter dem Einfluss der Binnenwanderung." Jahrbuch für $\mathrm{Na}$ tionalókonomie und Statistik 44:1-34, 161182.

Wrigley, E. A.

1961 Industrial Growth and Population Change. Cambridge: Cambridge University Press. 